\title{
Can Shaming Punishments Educate?
}

\author{
Stephen P. Garvey $\dagger$
}

\section{INTRODUCTION}

An unusual thing is happening in the world of punishment. Different forms of punishment are starting to appear that challenge conventional notions of what punishment is all about.

In colonial America, the fledgling state had a rich array of afflictions it could draw upon to punish criminal offenders. ${ }^{1}$ Death was one. Offenders would be publicly dispatched amid great ceremony, which was sometimes sober and somber, and sometimes not. Whipping, too, was an option, again usually in full display before an onlooking public. ${ }^{2}$ Fines were widely used, ${ }^{3}$ as at times were stocks, pillories, bilboes, branks, brands, ducking stools, and, on very rare occasions, burning. ${ }^{4}$ Missing, because it

† Associate Professor, Cornell Law School. B.A., Colgate University, 1987; M.Phil., Oxford University, 1989; J.D., Yale University, 1992. Thanks to Kathy Abrams, Calum Carmichael, Steven Clymer, Cynthia Farina, Robert Green, George Hay, Sheri Johnson, Dan Kahan, Lily Kahng, Toni Massaro, Russell Osgood, Eric Posner, Steve Shiffrin, Gary Simson, participants at Cornell Law School's faculty workshop, and students in my criminal law seminar for their helpful comments. Thanks also to Carolyn Lee for outstanding research assistance.

${ }_{1}$ See, for example, Lawrence M. Friedman, Crime and Punishment in American History 41-44 (Basic Books 1993). For additional descriptions of colonial punishment, see Michael Stephen Hindus, Prison and Plantation: Crime, Justice, and Authority in Massachusetts and South Carolina, 1767-1878 99-124 (North Carolina 1980); Edwin Powers, Crime and Punishment in Early Massachusetts, 1620-1692 195-211 (Beacon 1966); Raphael Semmes, Crime and Punishment in Early Maryland 38-40 (Patterson Smith 1970); Donna J. Spindel, Crime and Society in North Carolina, 1663-1776 116-37 (Louisiana State 1989).

${ }^{2}$ See, for example, Friedman, Crime and Punishment at 37 ("Whipping was an extremely common punishment throughout the colonies, especially for servants and slaves.").

" In fact, fines-not shaming penalties-were the "drudge-horse" of colonial justice. Friedman, Crime and Punishment at 38. See also Kathleen Preyer, Penal Measures in the American Colonies, 26 Am J Legal Hist 326, 349 (1982) ("Though hardly in disuse, those punishments so dear to the lore about colonial America are, from the data we have at present, clearly not a very characteristic mode of punishment.").

- See Friedman, Crime and Punishment at 36-41 (describing, among other punishments, branding letters on the foreheads of convicted criminals); Preyer, $26 \mathrm{Am} J$ Legal Hist at 334-35 (discussing punishments such as putting a cleft stick on a forked tongue for swearing). See also Linda Kealey, Patterns of Punishment: Massachusetts in the Eighteenth Century, 30 Am J Legal Hist 163, 163 (1986). Compare generally William Andrews, Old-Time Punishments (William Andrews 1890) (describing older English penalties). 
had not yet come into full bloom, was the prison. ${ }^{5}$

Today, in contrast, two options dominate the penal imagination: imprisonment and simple probation. From time to time we do use a collection of intermediate sanctions between these extremes that includes traditional impositions like community service and fines, as well as more recent innovations like intensive probation supervision, house arrest, and boot camps. ${ }^{6}$ Still, "[b]etween overcrowded prisons and even more overcrowded probation, there is a near-vacuum . ... . Prison and probation continue to represent our punitive orthodoxy. But orthodoxy invites challenge. Set aside the standard package of intermediate sanctions and consider instead the following collection of sanctions that have attracted considerable attention in the legal literature and popular press alike: ${ }^{8}$

- A woman convicted of drug possession is ordered to stand on a street corner wearing a sign saying, "I got caught possessing cocaine. Ordered by Judge Whitfield."

5 For accounts of the rise of the penitentiary in the United States, see generally Adam J. Hirsch, The Rise of the Penitentiary: Prisons and Punishment in Early America (Yale 1992); David J. Rothman, Discovery of the Asylum (Little, Brown 2d ed 1990). Some designers of the early penitentiary envisioned that members of the public would be allowed inside and inmates put "on display as if in a zoo." Friedman, Crime and Punishment at 7778 (cited in note 1 ).

- See, for example, Michael Tonry and Mary Lynch, Intermediate Sanctions, in Michael Tonry, ed, 20 Crime and Justice: A Review of Research 99, 99-101 (1996) (providing an overview of latest research on intermediate sanctions).

7 Norval Morris and Michael Tonry, Between Prison and Probation 14 (Oxford 1990).

8 For recent student commentary, see generally Jon A. Brilliant, Note, The Modern Day Scarlet Letter: A Critical Analysis of Modern Probation Conditions, 1989 Duke L J 1357; Brian C. Erb, Developments in the Law-Creative Probation Conditions: Putting the "Unusual" Back in "Cruel and Unusual" After Bateman, 24 Willamette L Rev 1155 (1988); Jeffrey C. Filcik, Recent Development-Signs of the Times: Scarlet Letter Probation Conditions, 37 Wash U J Urban \& Contemp L 291 (1990); Rosilind K. Kelley, Comment, Sentenced to Wear the Scarlet Letter: Judicial Innovations in Sentencing-Are They Constitutional?, 93 Dickinson L Rev 759 (1989); Lemore H. Tavill, Note, Scarlet Letter Punishment: Yesterday's Outlawed Penalty is Today's Probation Condition, 36 Cleve St L Rev 613 (1988). See also Marjorie H. Levin, Note, Corporate Probation Conditions: Judicial Creativity or Abuse of Discretion, 52 Fordham L Rev 637, 641-57 (1984) (describing the use of nonmonetary sanctions on corporations).

s "Eye on America," CBS Morning News (CBS television broadcast, May 16, 1997). In addition, a former stockbroker convicted of embezzlement is ordered to wear a similar sign saying, "I am a convicted thief. Ordered by Judge Whitfield." Id. See also Creative Judge Signs Off on Punishment, Tulsa World C8 (Apr 16, 1997) (A convicted burglar required to wear a sign reading, "I am a convicted thief."); Jeanie Russell, Shame! Shame! Shame!, Good Housekeeping 102 (Aug 1, 1997) (People caught shoplifting required to march in front of the store with sign reading, "I STOLE FROM THIS STORE."); Staff, Woman Gets Probation, Scarlet T-Shirt, Houston Chron A24 (May 25, 1994) (A woman convicted of shoplifting required to wear T-shirt inscribed, "I was convicted of shoplifting."); Ann Woolner, When The Sentence Is A Shame, Am Law 34 (Nov 1997) (A man convicted of theft 


\section{- An offender convicted of DWI is ordered to paste a bumper sticker on his car that reads, "CONVICTED: DWI."10 Another DWI offender is ordered to attend church. ${ }^{11}$}

- Men convicted of soliciting prostitutes in Kansas City, Missouri, have their faces and names displayed on the local community access channel in a program popularly known as "John TV."12 Men in San Francisco, California, are required to attend the "School for Johns," where former prostitutes lecture them about life on the streets. ${ }^{13}$

in Hinesville, Georgia required as probation condition to walk around county courthouse for thirty hours in two-hour stints with sign reading, "I AM A CONVICTED THIEF.").

Signs also have been used for sex offenders. See, for example, State $v$ Bateman, $95 \mathrm{Or}$ App 456, 771 P2d 314, 316, 322 (1989) (en banc), overruled in part by State $v$ Anderson, 113 Or App 416, 833 P2d 321, 323 (1992) (en banc) (A convicted sex offender is required to post on the front door of his home, and on the doors of any car he drives, a sign that reads, "DANGEROUS SEX OFFENDER-NO CHILDREN ALLOWED."). See also State $v$ Burdin, 924 SW2d 82, 84 (Tenn 1996) (A convicted felon is ordered to post sign describing himself as convicted child molester.); Martha Brannigan and Karen Blumenthal, Courts Using Humiliation as Punishment, Wall St J 11 (Nov 9, 1989) (A similar sanction imposed on sex offender in Rhode Island.).

${ }^{10}$ People v Letterlough, 86 NY2d 259, 655 NE2d 146, 147 (1995). See also Goldschmitt $v$ State, 490 S2d 123, 124 (Fla Dist Ct App 1986) (per curiam) (requiring a convicted drunk driver to affix to his car a bumper sticker reading, "Convicted D.U.I.-Restricted License"). Shaming plates also have been offered to drunk drivers in the former Soviet republic of Estonia as an alternative to losing their licenses, but few seem to take it. See Soviet Drivers Pass on "Shame Plates", LA Times 25 (Jan 25, 1987).

"See Joe Cook, Legal Quirk: The ACLU Versus Judge Thomas: Quirk Over Sentencing Defendants to Church, Liberty 11 (Dec 1995). See also ACLU Attacks Church Attendance Ruling, Wash Post H12 (May 3, 1986) (A thief is required as condition of probation to attend church.); Martha Middleton, Sentencing: The Alternatives, Natl L J 1 (Apr 23, 1984) (A "bad-check writer" sentenced "to attend church once a week for three years."); Paul J. Toomey, Rude Driver Ordered to Serve Time in Church, The Record A1 (Feb 1, 1996) (A man who intentionally bumped a vehicle at a toll plaza ordered to get counseling from his minister.).

${ }^{12}$ See Edward Walsh, Kansas City Tunes In as New Program Aims at Sex Trade: "John TV", Wash Post A3 (July 8, 1997). See also John Larrabee, Fighting crime with a dose of shame, USA Today $3 A$ (June 19, 1995) (describing similar programs in Miami, Florida and La Mesa, California); The Shame Game, Boston Globe 14 (Apr 2, 1996) (editorial) (mentioning similar effort by Boston police); Jane Prendergast, Prostitution John Forced to Wear "Scarlet Letter", Cin Enq A1 (Jan 30, 1998) (reporting a man convicted of soliciting a prostitute was ordered to "wear[ ] a sign advertising that he tried to buy sex and got caught"). Compare Larrabee, Fighting crime, USA Today at 3A (describing local police captain in Taunton, Massachusetts who reads on local cable TV the names and alleged crimes of everyone arrested in the previous week). See generally Courtney Guyton Persons, Note, Sex in the Sunlight: The Effectiveness, Efficiency, Constitutionality, and Advisability of Publishing Names and Pictures of Prostitutes' Patrons, 49 Vand L Rev 1525 (1996) (evaluating programs that publicize names of men who solicit prostitutes).

${ }^{13}$ See Michael J. Ybarra, Patrons Given a Graphic View of Prostitution, NY Times 18 (May 12, 1996). See also Alan Deutschman, The School for Johns, Playboy 46 (July 1, 1996). 
- A landlord in Syracuse, New York, whose building was condemned as a slum, is ordered to post a four-foot square sign on the building that lists his name together with his phone number. ${ }^{14}$ A New York City landlord is sentenced to house arrest in one of his own slums. ${ }^{15}$

- A burglar in Memphis, Tennessee is ordered to allow his victim, accompanied by law enforcement personnel, to enter his home unannounced and take something of comparable value to what he stole. ${ }^{16}$

- A juvenile convicted of throwing a brick, which blinded the victim in one eye, is ordered to wear an eye patch. He is permitted to take it off only when he sleeps. ${ }^{17}$

- A man convicted of stealing $\$ 49$ worth of T-bone steaks is ordered to give a "shaming speech," approved in advance by the trial court, on the steps of the local courthouse. ${ }^{18}$

${ }^{14}$ See Edward M. Eveld, Shame makes a comeback, Kan City Star A1 (May 16, 1997). See also Larrabee, Fighting crime, USA Today at 3A (cited in note 12) (reporting similar sanction used against landlord in Framingham, Massachusetts); Mike Nichols, Alderman proposes shame signs for slum landlords, Milwaukee J Sent 1 (Sept 17, 1997) (describing proposal to use similar sanctions against slumlords in Milwaukee and noting that "Chicago recently adopted its own version of the Syracuse ordinance").

${ }^{15}$ See Instead of Jail: "Welcome, Reptile!", NY Times A22 (Feb 17, 1988). See also Paul Feldman, More Counts on Slumlord Filed by City, LA Times 1 (Feb 20, 1986) (Similar sanction imposed on Los Angeles landlord.); Judge Orders Landlord to Live in His Own Slum, Chi Trib C10 (Jan 20, 1992) (Newark landlord); Scot Lehigh, Landlord Didn't Reside, Remain' in Unheated Flat, Boston Globe 47 (Nov 24, 1989) (Boston landlord). Similarly, a man convicted of cruelty to animals for leaving three puppies to die at a city dump during winter was given the option of spending two nights outside at the dump. See Accused Puppy Abuser Doesn't Like Cold, UPI (Feb 12, 1982).

Other landlords have been ordered personally to make the necessary repairs to their dilapidated housing. See Alexis Jetter, Judge: Slumlord to Make Repairs, Newsday 33 (Dec 26, 1988). See also Edward A. Adams, Unusual Sentence for Landlord is Upheld, NY L J 1 (May 28, 1991) (A landlord is ordered to work with professional consultants to design a rehabilitation plan for his buildings.).

${ }^{16}$ See Joe B. Brown, Judge Devises Instructional Penalties, NY Times B16 (Feb 13, 1993) (noting that "victims often take back from burglars what was taken from them"). See also Paula Dittrick, Judges Turn to Alternative Sentences, UPI (Oct 24, 1982) (noting North Carolina program in which housebreakers return to crime scene and meet with victims in the hope that the offender will "realize the emotional impact the victim experienced"); Humiliation: Judges Say Crooks Should be Made To Feel Ashamed, Salt Lake Trib A1 (Dec 17, 1996) (describing similar punishment in Utah).

${ }^{1}$ See Debbie Salamone, Judge Orders Teen Who Maimed Tourists to Wear Eye Patch, Orlando Sent A1 (May 30, 1996). See also A Fine Precedent, Orlando Sent A6 (June 4, 1996) (editorial).

${ }^{13}$ See David Doege, Shaming Sentences Group is Diverse, Milwaukee J Sent 1 (Apr 6, 1997). See also Judge Orders Man To Confess Crime in Church, UPI (Jan 7, 1984). 
- A man who rammed his car into another car being driven by an interracial couple is required to watch "Mississippi Burning. ${ }^{19}$

- A man convicted of selling fake insurance policies to Maryland horse trainers is required to clean out the stalls of Baltimore's mounted police unit. ${ }^{20}$

\section{What's going on here? ${ }^{21}$}

One possibility is shame. On this view, these punishments expose the offender to public view and heap ignominy upon him in a way that other alternative sanctions to imprisonment, like fines and community service, do not. Reminiscent of Hawthorne's famous scarlet letter, ${ }^{22}$ they shame offenders, and purposefully so, with modern methods of communication serving as "virtual pil-

19 See Man Sentenced to See "Mississippi Burning", UPI (Mar 9, 1989).

${ }^{20}$ See Maryland Stable Duty Sentence, Wash Post D5 (Aug 10, 1989).

${ }^{21}$ For present purposes, I leave aside public notification statutes, like Megan's Law, and biological interventions, like chemical castration, both of which also have attracted considerable attention. As I see it, the primary aim of these sanctions is neither to shame nor to educate.

Public notification statutes appear designed primarily to protect third parties. Compare E.B. $v$ Verniero, 119 F3d 1077, 1100 (3d Cir 1997), rehearing en banc denied, 127 F3d 298 (1997) (concluding that "various forms of state warnings about threats to public safety provide more apt analogies" to public notification statutes than do shaming penalties). Accord Doe v Pataki, 120 F3d 1263, 1284 (2d Cir 1997), amended, rehearing denied, 1997 US App LEXIS 26426 (2d Cir) ("[N]otification is . . . intended to serve the goals of protecting the public and facilitating future law enforcement efforts."). See also Abril R. Bedarf, Comment, Examining Sex Offender Community Notification Laws, 83 Cal L Rev 885, 906 (1995) ("Sex offender notification laws are premised on the belief that community knowledge about sex offenders will empower residents to protect themselves.").

Biological interventions appear designed primarily to incapacitate selectively. Compare Steven S. Kan, Corporal Punishment and Optimal Incapacitation, $25 \mathrm{~J}$ Legal Stud 121, 130 (1996) (arguing for use of temporary incapacitative measures targeted at particular organs implicated in criminal wrongdoing). See also Sheldon Gelman, The Biological Alteration Cases, $36 \mathrm{Wm} \&$ Mary L Rev 1203, 1213 (1995) (arguing that biological interventions should be subject to "strict scrutiny"); Connie S. Rosati, A Study of Internal Punishments, 1994 Wis L Rev 123, 125 (offering a "qualified, philosophical defense of internal punishment").

Nor do I directly address any special problems raised by so-called "publicity" sanctions imposed on corporate criminal defendants. See generally Andrea A. Curcio, Painful Publicity-An Alternative Punitive Damage Sanction, 45 DePaul L Rev 341, 343 (1996) (proposing that "companies' wrongdoing should be broadcast over the Internet on a dedicated World Wide Web page entitled Punitive Damages Awards"'); Jeffrey S. Parker, Rules Without ... : Some Critical Reflections on the Federal Sentencing Guidelines, 71 Wash U L Q 397, 426-32 (1993) (arguing that the Federal Sentencing Guideline authorizing adverse publicity is ultra vires); Andrew Cowan, Note, Scarlet Letters for Corporations? Punishment by Publicity Under the New Sentencing Guidelines, 65 S Cal L Rev 2387, 2389 (1992) (concluding that federal "guidelines for adverse publicity ... provide an innovative and theoretically sound sanction that judges should have at their disposal").

2 See Nathaniel Hawthorne, The Scarlet Letter 57 (first published 1850) (St Martin's 1992) ("[T] 
lor[ies]. ${ }^{23}$ Moreover, at a time when the costs of imprisonment consume ever larger shares of state budgets, ${ }^{24}$ shame may serve as a politically viable and cost-effective way of achieving deterrence, specific and general, as well as of satisfying the legitimate demands of retribution.

I want to suggest, however, that something else lies behind some of these sanctions. Although shame may explain many of them, it cannot account for them all. For example, shame involves an audience, ${ }^{25}$ and while some of these sanctions require an offender to publicize his offense to an audience that ordinarily would be unaware of it, not all of them do. Some of them are carried out in relative privacy. If not shame, then what is the appeal?

The answer I give is education, but education of a peculiar sort. The education $I$ have in mind is peculiar because it trades on the widely discredited though strangely enduring principle of lex talionis, or law of talion, popularly known as an "eye for an eye. ${ }^{\text {26 }}$

A literal reading of lex talionis is routinely derided as a senselessly cruel formula for punishment, and rightly so. A better reading, which I advance here, eschews this literal construction and instead construes the talionic principle against the background of a theory of punishment known as the moral education, or moral reform, theory. As explained more fully below, ${ }^{27}$ this appealing but largely neglected theory tries to transcend the ongoing debate between retributivism and utilitarianism and to avoid

${ }^{23}$ Larrabee, Fighting crime, USA Today at 3A (cited in note 12). See also Now, CyberPillory Stocks, Natl L J A8 (July 7, 1997) (names of offenders posted on World Wide Web); Michael Schrage, Should Virus Carriers Wear a Scarlet V?, ComputerWorld 37B (Jan 27, 1997) (urging publication of names of those who introduce viruses into computer networks).

${ }^{24}$ See, for example, Stan C. Proband, Corrections Leads State Budget Increases in FY 1997, Overcrowded Times 4 (Aug 1997) ("[T]otal state appropriations for corrections were projected to increase by 6.2 percent in FY 1997, the biggest increase of any category.").

${ }^{25}$ See, for example, Gabriele Taylor, Pride, Shame, and Guilt: Emotions of SelfAssessment 53 (Clarendon 1985) ("[S]hame introduces . . . the notion of an audience, for feeling shame is connected with the thought that eyes are upon one.").

${ }^{23}$ See Black's Law Dictionary 913 (6th ed 1990) (Lex talionis "requires the infliction upon a wrongdoer of the same injury which he has caused to another" and is "[e]xpressed in the Mosaic law by the formula, "an eye for an eye; a tooth for a tooth,' etc."). The "life for life, eye for eye, tooth for tooth" formulation of lex talionis appears only in the Bible, most famously in Exodus 21:23-25, and Leviticus 24:18, and may have enjoined the literal, postmortem mutilation of offenders who had been executed for capital offenses. See Calum Carmichael, The Spirit of Biblical Law 104, 107 (Georgia 1996) ("[T]he formula means exactly what it says .... It means a life for a life-to be followed by the systematic mutilation of the offender's corpse.").

${ }^{27}$ See Part III.A. 
the pitfalls of rehabilitation. It recommends the infliction of hardship on an offender that "mirrors" his own wrongdoing in order to morally "educate" him, to make him see the error of his ways, and ideally, to lead him to repentance. Punishments should aim to reflect back on the offender what he has done to his victim, which is the essence of the talionic principle.

Punishments widely described as "shaming" penalties thus come in two basic but very different forms: those that rely on public exposure and aim at shaming; and those that do not rely on public exposure and aim at educating. The rise of these punishments may turn out to be a short-lived blip in the evolution of penal sanctions. ${ }^{28}$ Indeed, many of these sanctions appear to be largely the work of a handful of especially innovative judges. ${ }^{29}$ Yet, if these sanctions do become a more prevalent feature of our punitive practices, ${ }^{30}$ judges should appreciate that they reflect two very different approaches to the problem of punishment.

In Part I, I introduce the shaming and educating models of punishment. I distinguish two dimensions of punishment-expressive and justificatory-that give the models their structure and explain how the models differ from one another along each dimension.

In Part II, I look more closely at the shaming model. ${ }^{31}$ Under the right circumstances shaming may live up to its billing as a cost effective and politically viable alternative to imprisonment. But shame has its problems. Most importantly, it menaces certain ideals that any morally respectable mode of punishment should honor, not the least of which is human dignity. ${ }^{32}$

See, for example, Steven Greenhut, Gimmicky Judges' 'Shame' Sanctions Unlikely to Curb Crime, Milwaukee J Sent A11 (Apr 13, 1997) (arguing against the adoption of shaming sanctions).

D Some of these judges have been accused of using creative sentencing as a publicity stunt to gain reelection. See, for example, Brown, Instructional Penalties, NY Times at B16 (cited in note 16).

${ }^{30}$ See, for example, Toni M. Massaro, The Meanings of Shame: Implications for Legal Reform, 3 Psych, Pub Pol, \& L 645, 689 (1997) ("Although these sanctions began as isolated events, they have now captured judicial and popular attention in ways that feed into the more general cultural critiques that blame our shamelessness for a host of social ills, and that may lead to their proliferation.").

"See Dan Kahan, What Do Alternative Sanctions Mean?, 63 U Chi L Rev 591, 630-53 (1996) (developing the shaming model).

22 Shaming punishments can be challenged on constitutional grounds, including the First Amendment's guarantees of freedom of speech and religion and the Eighth Amendment's prohibition against cruel and unusual punishments. See, for example, Goldschmitt, 490 S2d at 125-26 (entertaining and rejecting First and Eighth Amendment challenges to requiring "CONVICTED D.U.I.-RESTRICTED LICENSE" bumper sticker as probation condition). See also Brilliant, Note, 1989 Duke L J at 1385 (cited in note 8) (concluding that scarlet letter probation conditions "constitute punishment ... [and] should be subject 
Accordingly, in Part III, I develop an alternative model, which I call the educating model. For many creative punishments, this model is descriptively more accurate than shame. Moreover, it supplies them with a different and more appealing normative foundation. Ironically, the cornerstone of that foundation is, I suggest, none other than the principle of lex talionis. Now, one can certainly read that principle to support ugly and cruel forms of punishment, but again, I link the talionic principle to the moral education theory of punishment in which it functions as a mechanism of moral reform.

Finally, in Part IV, I turn to the actual practice of educating through punishment. I examine a representative sample of educating penalties and contrast them with their shaming counterparts. Some of these penalties comport nicely with the moral education theory and under the right circumstances should be encouraged. Others, however, teach no lesson, or worse, teach the wrong lesson and should be discouraged.

\section{DIMENSIONS OF THE MODELS}

Punishment has two dimensions: expressive and justificatory. ${ }^{33}$ Both of the models of creative punishments I develop here are built on these two dimensions, but the models differ significantly along each of them.

The justificatory dimension of punishment should be familiar. It answers the questions: What justifies punishment? What is the moral point of inflicting hardship on criminal wrongdoers? The traditional answers, of course, come from retributivism and utilitarianism. ${ }^{34}$ Retributivism looks to the past and finds pun-

to the eighth amendment's 'dignity of man' standard"). I take no position on these constitutional questions.

${ }^{33}$ Although these two dimensions are treated separately in the analysis that follows, their precise relationship is unclear. According to some accounts, the expressive dimension of punishment is analytically independent of the justificatory dimension. See, for example, Joel Feinberg, The Expressive Function of Punishment, reprinted in Joel Feinberg, Doing and Deserving 98 (Princeton 1970). Other accounts, in contrast, imply that the expressive dimension may reduce to the justificatory dimension. For example, the expressive dimension, and especially the function it serves in morally condemning the offender's conduct, is sometimes taken to be a form of retributivism. See, for example, Robert Nozick, Philosophical Explanations 370 (Harvard 1981) ("Retributive punishment is an act of communicative behavior."). See also Jean Hampton, An Expressive Theory of Retribution, in Wesley Cragg, ed, Retributivism and Its Critics 1, 2-3 (Steiner 1992) ("This idea that punishment expresses condemnation or censure looks retributive."). Alternatively, the expressive dimension is taken to be a form of utilitarianism. See, for example, Michael S. Moore, The Moral Worth of Retribution, in Ferdinand Schoeman, ed, Responsibility, Character, and the Emotions: New Essays in Moral Psychology 179, 181 (Oxford 1987).

${ }^{34}$ See generally Herbert L. Packer, The Limits of the Criminal Sanction 35-61 (Stanford 1968) (discussing traditional justifications of punishment). 
ishment justified if and only if the offender deserves it. The point of punishment is to do justice. Utilitarianism, in contrast, looks to the future and finds punishment justified if and only if it enhances social utility. The point is to reduce crime.

The expressive dimension of punishment, however, is less familiar. Longstanding philosophical analysis holds that punishment is the "infliction of hard treatment by an authority on a person for his failure in some respect (usually an infraction of a rule or command). ${ }^{335}$ Yet this analysis is incomplete, because it ignores much of what makes punishment a distinctive social practice. Punishment does indeed impose material "hard treatment," but it does more. It speaks. It says something. ${ }^{36}$ Punishment, in other words, is a form of language. ${ }^{37}$ But what does punishment say?

At the very least, it says that the offender's act was wrong and will not be tolerated. In a word, punishment, unlike civil sanctions, condemns. ${ }^{38}$ It is "a conventional device for the expression of attitudes of resentment and indignation. ${ }^{339}$ It expresses condemnation much like champagne at a wedding expresses celebration, or black dress at a funeral expresses mourning. The conventions or social norms by which punishment "speaks" are a product or artifact of culture and history. Of course, these conventions, like those governing natural languages, do change, but at any particular moment they are relatively stable and impose "objective" constraints on how we can effectively express our condemnation. ${ }^{40}$ We could not, for example, condemn an offender's

${ }^{36}$ Feinberg, Expressive Function at 95 (cited in note 33), citing Antony G. Flew, The Justification of Punishment, 29 Phil 289, 291-307 (1954); Stanley I. Benn, An Approach to the Problems of Punishment, 33 Phil 325, 325-41 (1958); H.L.A. Hart, Prolegomenon to the Principles of Punishment, 60 Proceedings of the Aristotelian Society 1(1959-60).

*5 For the most influential discussion of this dimension, see Feinberg, Expressive Function at 98 (cited in note 33) ("Punishment ... has a symbolic significance largely missing from other kinds of penalties."). See also Igor Primoratz, Punishment as Language, 64 Phil 187, 188 (1989) (discussing the "main varieties of normative expressionism"); A.J. Skillen, How to Say Things with Walls, 55 Phil 509, 513-15 (1980) (distinguishing different senses of "expression"). Compare Michael Davis, Punishment as Language: Misleading Analogy for Desert Theorists, 10 L \& Phil 311, 312 (1991) (arguing that "expressionism adds nothing of value to (traditional) retributivism").

"17 Although these two aspects of punishment-material and expressive-are analytically distinct, they are related, because the material hardship imposed on an offender is the medium that conveys the message.

${ }^{3}$ See, for example, Henry M. Hart, Jr., The Aims of the Criminal Law, 23 L \& Contemp Probs 401, 404 (1958) ("What distinguishes a criminal from a civil sanction and all that distinguishes it, it is ventured, is the judgment of community condemnation which accompanies and justifies its imposition."); Paul Robinson, The Criminal-Civil Distinction and the Utility of Desert, 76 BU L Rev 201, 202 (1996) (noting that "criminal sanctions signal condemnation").

${ }^{39}$ Feinberg, Expressive Function at 98 (cited in note 33).

${ }^{40}$ See, for example, Kahan, $63 \mathrm{U}$ Chi L Rev at 597-98 (cited in note 31). See also Eliza- 
conduct by giving him a parade any more than we could mean "hot" by saying "cold." Despite our intentions, our efforts at communication would misfire.

These two dimensions-expressive and justificatory-structure the two models of creative punishments. In the shaming model, the expressive dimension of punishment is "monologic." When the state speaks through punishment, it condemns the offender's conduct, but that's all. It makes no pretense of saying anything more. Punishment thus forms an occasion for the state to speak to the offender (and the wider public), without seeking a response from him in turn. As for the justificatory dimension of punishment, the shaming model rests on the familiar theories of retributivism, deterrence, and rehabilitation. ${ }^{41}$

The educating model differs along both dimensions. Its expressive dimension is "dialogic." When the state speaks through punishment, it tries to engage the offender in a moral dialogue. As in the shaming model, the sanction imposed on the offender is intended to convey moral disapprobation and disapproval of his wrongdoing, but it aspires to do more. It tries to elicit a particular response from him. It attempts to show him why what he has done was wrong in the hope of getting him to repent. Such a response may not always be forthcoming, but that is all right. The model accepts the possibility of educative failure. In the educating model, therefore, punishment forms an occasion for the state to speak with the offender, not just at him.

The educating model also differs from the shaming model along the justificatory dimension. Whereas retribution, deterrence, and rehabilitation justify punishment under the shaming model, the moral education theory supplies the justification for punishment in the educating model. Although this theory is related to both retributivism and utilitarianism, it is distinct from both and reducible to neither. Nor is it simply rehabilitation by another name.

beth Anderson, Value in Ethics and Economics 18 (Harvard 1993) (Social norms provide a "publicly intelligible vehicle" by which to express valuations.); Cass Sunstein, Social Norms and Social Roles, 96 Colum L Rev 903, 917 (1996) ("Norms establish conventions about the meanings of actions.").

${ }^{4}$ See, for example, Toni M. Massaro, Shame, Culture, and American Criminal Law, 89 Mich L Rev 1880, 1891-99 (1991) (discussing shaming in the context of retributivism, deterrence, and rehabilitation). See also Kahan, $63 \mathrm{U}$ Chi $\mathrm{L}$ Rev at 601-05 (cited in note 31) (explaining how "expressive theory" can "inform" retributivism and deterrence). Shaming penalties also can "incapacitate" insofar as they publicize an offender's wrongdoing to third parties, who can then steer clear of him. See, for example, Massaro, 89 Mich L Rev at 1900. 
The various dimensions of each model will be fleshed out in more detail in the analysis that follows.

\section{The SHAMING MODEL}

Many creative punishments qualify as "shaming penalties." They require an offender to publicize his offense to an audience that under normal circumstances would be unaware of it; moreover, as a result of this publicity, the penalties may cause the offender to suffer an unpleasant-perhaps even painful-emotional experience, usually described as "shame."

Shaming penalties come in different forms. For example, an offender might be required to publicize his offense by standing in public view wearing a sign, ${ }^{42}$ by putting a bumper sticker on his car, ${ }^{43}$ by wearing a T-shirt, ${ }^{44}$ by placing a sign on his property, ${ }^{45}$ by giving a public speech, ${ }^{46}$ by taking out an ad in the local newspaper or in a trade magazine, ${ }^{47}$ or even by posting a message on the World Wide Web. ${ }^{48}$ While shame can be used to punish any offense, shaming penalties are typically reserved for sex and morals offenses (prostitution), commercial offenses (embezzlement), and minor offenses (shoplifting). ${ }^{49}$ First-time offenders are another favorite target of shame. ${ }^{50}$

But what is the appeal of shame?

\section{A. Shame's Appeal}

One possibility, which has been most ably developed and defended by Dan Kahan, is economic. ${ }^{51}$ According to Kahan, shame

${ }^{42}$ See, for example, Creative Judge Signs Off on Punishment, Tulsa World at C8 (cited in note 9).

${ }^{43}$ See, for example, Goldschmitt $v$ State, 490 S2d 123, 124 (Fla Dist Ct App 1986) (per curiam).

4 See, for example, Staff, Scarlet T-Shirt, Houston Chron at A24 (cited in note 9).

4s See, for example, Nichols, Slum Landlords, Milwaukee J Sent at 1 (cited in note 14).

* See, for example, Doege, Group is Diverse, Milwaukee J Sent at 1 (cited in note 18).

${ }^{47}$ See, for example, Julia C. Martinez, Judges Using 'Shame Punishment' More to Emphasize a Message, Fla Times-Union F1 (Feb 16, 1997) (noting that a butcher shop was ordered to place ad in local paper confessing that it had "sold meat that consisted in whole or in part of filthy, putrid and contaminated substances' and was 'unfit for human food").

${ }^{4}$ See, for example, Now, Cyberpillory Stocks, Natl L J at A8 (cited in note 23).

4" See, for example, James Q. Whitman, What Is Wrong with Inflicting Shame Sanctions?, 107 Yale L J 1055, 1064 (1998). Of course, shame also can be deployed against offenders imprisoned for more serious offenses. The recent reappearance of the chain gang is an example. See, for example, John Leland and Vern E. Smith, Back on the Chain Gang, Newsweek 58 (May 15, 1995); Brent Staples, The Chain Gang Show, NY Times Mag 62 (Sept 17, 1995).

so See Whitman, 107 Yale L J at 1064.

${ }^{11}$ Economics is not the only possibility. We can identify at least two others, one cultural, the other sociological. The cultural explanation links shame's appeal to a larger cul- 
may help solve an expensive public problem. ${ }^{52}$ The problem is this: Prison is both costly and overused. For some offenders, especially nonviolent ones, imprisonment is too harsh but straight probation is too lenient. We need something in between. The conventional alternatives to imprisonment and probation, mainly fines and community service, might work, but they present yet another problem. Judges, it seems, simply don't use them very much, ${ }^{53}$ or at least not as much as one might hope or expect. Why not? Kahan's answer, which at last gets us to shame, involves punishment's expressive dimension. ${ }^{54}$

tural critique. According to this critique, Americans have lost their sense of shame. For example, they appear on "Oprah" and talk of things their parents would never have dreamed of making public. From this perspective, the appeal of shaming penalties rests on the hope that they might help restore a lost sense of modesty. For a sampling of this cultural critique, see the essays collected in Digby Anderson, ed, This Will Hurt: The Restoration of Virtue and Civic Order (Social Affairs Unit 1995). See also James Twitchell, For Shame: The Loss of Common Decency in American Culture (St. Martin's 1997). For a strong critique of this Kulturkampf, see Massaro, 3 Psych, Pub Pol, \& L at 647 (cited in note 30 ) (" $[T]$ he new shame rhetoric ... often betrays no genuine concern for the people it condemns."). See also Whitman, 107 Yale L J at 1077 (cited in note 49) (describing Victorian critique of shaming penalties according to which such public displays "tended to loosen fetters of decent comportment") (emphasis added); Carl F. Horowitz, The Shaming Sham, Am Prospect 70-71 (Mar-Apr 1997) (paraphrasing Oliver Stone in stating that "shaming at heart is McCarthyist").

The sociological explanation links shame's appeal to the social function of punishment. Punishment, on this view, operates to condemn conduct that violates a society's moral code (or, in Durkheimian terms, its "collective conscience") and thereby reinforce that code. Emile Durkheim, The Division of Labor in Society 63 (Free Press 1984) (W.D. Halls, trans). In order to serve this function, punishment requires a public degradation ceremony. See Harold Garfinkel, Conditions of Successful Degradation Ceremonies, $61 \mathrm{Am} J$ Soc 420, 422-23 (1956) (outlining features of "status degradation ceremonies"). However, with the rise of the penitentiary as the dominant form of punishment, and the rise of plea bargaining as the criminal law's dominant mode of adjudication, no such ceremony exists in the modern world. Public shaming penalties thus represent society's effort to satisfy a basic functional need.

62 Kahan has appeared in support of shame on "The Today Show," on National Public Radio, and in the pages of The Wall Street Journal. See, for example, Using Shame and Guilt as Punishment for Crimes, "Weekend Edition," National Public Radio, (Mar 23, 1996) (radio transcript); Dan M. Kahan, It's a Shame We Have None, Wall St J A16 (Jan 15, 1997). See also Henry J. Reske, Scarlet Letter Sentences, ABA J 16 (Jan 1996) (highlighting Kahan's thesis). His ideas also have been applauded by conservative syndicated columnist George Will. See George F. Will, It's Cheaper Than Prison: Shame the Bad Guys, Sacramento Bee F2 (Feb 25, 1996). Even The New York Times, specifically mentioning Kahan's work, has given shame a cautious endorsement. See Alternative Sentencing, NY Times A16 (Jan 20, 1997) (editorial).

${ }^{\star 3}$ See Kahan, 63 U Chi L Rev at 591 (cited in note 31) (stating that "fines and community service ... are used sparingly and with great reluctance").

"The other possibility involves what Kahan refers to as the "conventional answer": the "failure of democratic politics." Id at 592 (cited in note 31). In other words, politicians have failed to explain to the public why these sanctions are indeed the right ones for the job, leaving the public unaware of just how punitive these sanctions can really be. See id. 
According to Kahan, some alternatives to imprisonment, such as fines and community service, are "expressively inadequate. ${ }^{\$ 55}$ Unlike imprisonment, ${ }^{56}$ they don't say the right thing (i.e., don't condemn as punishment should), or at least don't say the right thing clearly enough. Fines are expressively ambiguous punishments because they make it look like an offender can buy his way out of punishment, and most of us don't think criminal acts should be subject to market logic. ${ }^{57}$ Similarly, community service is ambiguous because service to the community is something civic-minded people do that wins them public praise and esteem, not something criminals do for punishment. ${ }^{58}$

In contrast, shaming penalties, Kahan claims, speak with a clear and commanding voice. They express moral condemnation of the offender's conduct far better than alternative sanctions such as fines and community service. ${ }^{59}$ Consequently, shaming penalties can win public approval as viable, cost-effective alternatives to imprisonment, whereas fines and community service, because of their expressive inadequacy, cannot. ${ }^{60}$ Indeed, according to Kahan, the "political acceptability of shaming penalties . . . is nearly an established fact."

Whether a particular sanction adequately expresses moral condemnation turns on that sanction's social meaning, which one can identify only through social and cultural interpretation. As a

\footnotetext{
${ }^{56}$ Id at 622. Kahan does not explore the social meaning of other intermediate sanctions, such as intensive probation supervision, house arrest, and boot camps. Nor do I.

so For an attempt to explain why imprisonment is shameful, see Eric Posner, Shaming Penalties in the Criminal Law 19-22 (1998) (unpublished manuscript on file with U Chi L Rev).

${ }^{87}$ See Kahan, 63 U Chi L Rev at 622-24 (cited in note 31) (discussing collective evidence for this claim).

${ }^{\text {ss }}$ See id at 627-29 (presenting expressions of this sentiment).

so Courts may therefore be more likely to impose shaming penalties on offenders whom they would otherwise sentence to short terms of imprisonment. See Kahan, $63 \mathrm{U}$ Chi L Rev at 635 (cited in note 31). By contrast, courts commonly impose non-shaming intermediate sanctions on offenders who would otherwise be sentenced to straight probation. See Tonry and Lynch, 20 Crime and Justice at 101-02 (cited in note 6). For alternatives to shaming that also combat this "net-widening" problem, see id at 134-37 (suggesting that shifting discretion to corrections officials or reworking existing sentencing guidelines can help solve this problem).

- However, fines and community service might be made to speak more clearly and express condemnation less equivocally by giving them a shaming twist, for example, by requiring an offender who performs community service to wear clothing that identifies him as an offender. See, for example, Kahan, $63 \mathrm{U}$ Chi L Rev at 649-52 (cited in note 31) (describing how shame might be used to supplement fines and community service). See also Russell, Good Housekeeping at 162 (cited in note 9) (describing probationer who was required to perform community service wearing a "fluorescent orange vest with a neon yellow band and bold black letters on front and back that read: probationer at work").

${ }^{61}$ Kahan, $63 \mathrm{U}$ Chi L Rev at 637 (cited in note 31).
} 
result, claims about the "social meaning" of any particular mode of punishment are bound to be more or less controversial. ${ }^{62}$ If shaming penalties do indeed express condemnation better than fines and community service, that may help explain why they might be more politically acceptable than the alternatives. But how do shaming penalties measure up against the requirements of retributivism, deterrence, and rehabilitation?

\section{B. Is Shame Justified?}

The answer is unclear. Doubts about shame exist on several grounds. In the final analysis, however, these doubts seem too weak to warrant rejecting shame altogether, especially if it can reduce our (over)reliance on imprisonment.

\section{Retribution.}

The core claim of retributivism holds that an offender should be punished, i.e., should experience suffering or hard treatment, because and only because he deserves it. ${ }^{63}$ Although this claim may be intuitively obvious, retributivists have said a great deal in defense of it. Indeed, the many "theories" of retributivism developed since Kant can fairly be seen as efforts to elaborate upon this central proposition. ${ }^{64}$ Insofar as shaming penalties inflict de-

See id at 607 (noting the difficulty of empirically analyzing social meaning). However, a surprisingly high degree of consensus exists among people over the severity of alternative sanctions when they are fully informed about what kinds of deprivations those sanctions entail. See, for example, Robert E. Harlow, John M. Darley, and Paul H. Robinson, The Severity of Intermediate Penal Sanctions: A Psychophysical Scaling Approach for Obtaining Community Perceptions, $11 \mathrm{~J}$ Quant Criminol 71, 86 (1995) (“'TThere was a reasonable consensus about the relative severities of the various alternative[ ] [sanctions] that we examined.").

* See, for example, Moore, Moral Worth at 179 (cited in note 33) ("A retributivist punishes because, and only because, the offender deserves it.").

- For an effort to sort out various forms of retributivism, see John Cottingham, Varieties of Retribution, 29 Phil Q 238, 238-45 (1979) (identifying nine varieties of retributivism).

For elaborations upon the basic retributive claim, see Moore, Moral Worth at 183 (cited in note 33) (retribution as best account of more particular moral judgment); Wojciech Sadurski, Giving Desert Its Due: Social Justice and Legal Theory 225-33 (D. Reidel 1985) (retribution as balancing of benefits and burdens); George Sher, Desert 69-90 (Princeton 1987) (same); Andrew von Hirsch, Censure and Sanctions 7 (Clarendon 1993) (retribution as expression of condemnation); Jean Hampton, A New Theory of Retribution, in R.G. Frey and Christopher W. Morris, eds, Liability and Responsibility: Essays in Law and Morals 377, 396 (Cambridge 1991) (retribution as symbolic defeat of wrongdoer); Herbert Morris, Persons and Punishment, 52 Monist 475, 477-78 (1968) (retribution as balancing of benefits and burdens). 
served suffering on an offender, shame appears to enjoy solid retributivist backing. ${ }^{65}$

From a retributivist perspective, the problem with shame is not whether it inflicts suffering but whether it inflicts proportional suffering. Retributivism insists not only that suffering be deserved, but also that the "severity" of the suffering be proportional to the "moral seriousness" or "moral blameworthiness" of the offense. ${ }^{66}$ Indeed, its insistence on proportionality is one of the main sources of retributivism's appeal.

When dealing with fines or imprisonment, which are measurable in terms of dollars and time, respectively, claims about proportionality between the crime and the punishment make sense. ${ }^{67}$ The thinking goes roughly like this: First, find some way to evaluate the comparative moral seriousness of various offenses, ${ }^{68}$ then rank them from most to least serious. Next, rank the universe of possible punishments from most to least severe. ${ }^{69}$ Then match the worst offense with the most severe punishment and work down from there. The task, of course, is much more complicated than this simple picture suggests. ${ }^{70}$ But it is not impossible. Indeed, the sentencing guidelines of many states reflect

${ }^{\infty 5}$ See, for example, Kahan, 63 U Chi L Rev at 602 (cited in note 31) (arguing that the "proper retributive punishment is the one that appropriately expresses condemnation," which shaming penalties do); Whitman, 107 Yale L J at 1062 (cited in note 49) ("[S]hame sanctions ... seem beautifully retributive.").

" See, for example, Moore, Moral Worth at 180 (cited in note 33) (Retributivists "are committed to the principle that punishment should be graded in proportion to desert.").

" See, for example, Michael Davis, How to Make the Punishment Fit the Crime, 93 Ethics 726, 736-42 (1983) (describing the proper method for scaling penalties). See also John Kleinig, Punishment and Desert 115-20 (Martinus Nijhoff 1973) (same); C.L. Ten, Crime, Guilt, and Punishment 154-55 (Oxford 1987) (same); Andrew von Hirsch, Doing Justice: The Choice of Punishments 132-40 (Northeastern 1976) (same).

* See, for example, Ten, Crime at 155 (The "moral seriousness of an offence is a function of two major factors - the harm done by the offence and the culpability of the offender as indicated by his mental state at the time of committing the offence."). Grades of culpability are usually ranked by reference to traditional categories of mens rea. For an effort to grade degrees of criminal harm, see Andrew von Hirsch and Nils Jareborg, Gauging Criminal Harm: A Living Standard Analysis, 11 Oxford J Legal Stud 1, 7-16 (1991) (arguing that the degree of criminal harm should be determined by the extent to which it diminishes the victim's "quality of life").

* See, for example, von Hirsch, Censure at 33-35 (cited in note 64) (defending "living standard" method for assessing the severity of criminal penalties); Paul Robinson and John M. Darley, The Utility of Desert, $91 \mathrm{Nw}$ U L Rev 453, 488 (1995) (arguing "for a criminal law based upon principles of desert, specifically, principles of desert as shared by the community").

${ }^{70}$ For example, one needs some way to "anchor" the penalty scale or, in other words, to establish cardinal, and not simply ordinal, rankings. See, for example, von Hirsch, Censure at 36-46 (cited in note 64). See also Lawrence Crocker, The Upper Limit of Just Punishment, 41 Emory L J 1059, 1071-72 (1992) (arguing that lex talionis is an "instance" of a broader principle of reciprocity and "can be seen as providing an upper limit for criminal punishment"). 
the conviction that the task can be successfully accomplished, at least when dealing with terms of imprisonment. ${ }^{71}$

Shame complicates this picture. ${ }^{72}$ Insofar as shaming penalties, unlike fines and imprisonment, are intended to make an offender's actual emotional response a part of the severity of the sanction, they make the proportionality calculus much more difficult, increasing the risk of disproportionate punishment. If the retributive "bite" of shaming penalties comes from getting the offender actually to experience the adverse and unpleasant emotion of shame, judges will have a tough time figuring out just which offenders will have that experience (and how much they will suffer as a result) and which will not. ${ }^{73}$ And they will at least sometimes get it wrong if they try.

Shaming penalties may be disproportionately too weak, or disproportionately too strong. First, shame may be too weak and thus not "work" at all on certain offenders, especially those who are socially alienated and disaffected. Shame depends on an offender having attachments to others in whose eyes he or she can, as a result of those attachments, suffer shame. ${ }^{74}$ An offender has to care what others think about him; otherwise, shame can get no grip on him. The broader and deeper his attachments, the greater will be his shame. ${ }^{75}$ If he lacks the requisite attachments, how-

${ }^{11}$ Compare Michael Tonry, Sentencing Matters 13-15 (Oxford 1996) (explaining how many sentencing guidelines are based on "just deserts" rationale but criticizing these guidelines for ignoring morally relevant differences between offenders).

72 More traditional intermediate sanctions (for example, community service, intensive probation supervision, house arrest, and boot camp) also make proportionality analysis more difficult. For efforts to develop ways to compare the "severity" of these intermediate sanctions with each other and with imprisonment, see Harlow, Darley, and Robinson, $11 \mathrm{~J}$ Quant Criminol at 75-76 (cited in note 62) (using "cross-modality matching of magnitude scaling techniques" to compare relative severity of intermediate sanctions); von Hirsch, Censure at 34-35 (cited in note 64) (defending "interest-analysis" approach to measuring severity of punishments); Martha F. Schiff, Gauging the Intensity of Traditional and Intermediate Punishments: Developing the Criminal Penalty Severity Scale 55-58 (1992) (unpublished dissertation on file with the U Chi L Rev) (same).

${ }^{73}$ See, for example, Massaro, 3 Psych, Pub Pol, \& L at 655 (cited in note 30) ("The emotional impact [of shaming a person] may range from none, to mild discomfort, to a profound and complete loss of self that inspires a desire to die.").

${ }^{74}$ Sociologists sometimes draw a distinction between shame cultures and guilt cultures. Japan is usually presented as a paradigmatic shame culture, while the United States is often presented as a paradigmatic guilt culture. See, for example, Ruth Benedict, The Chrysanthemum and the Sword: Patterns of Japanese Culture 222-25 (Houghton Mifflin 1946). This distinction may or may not be a useful tool for analyzing culture. See, for example, Millie R. Creighton, Revisiting Shame and Guilt Cultures: A Forty-Year Pilgrimage, 18 Ethos 279, 280-92 (1990) (defending the distinction). Nevertheless, it hardly supports the claim that citizens of the United States are immune to the emotional experience of shame.

${ }^{25}$ On the other hand, it is also more likely that his community will forgive him and accept him back into the fold if he expresses remorse for his wrongdoing. 
ever, he will, in a word, be "shameless," and subjecting him to a shaming penalty will have little retributive bite. The same is true if his attachments run to a criminal subculture, in which case "shaming" him may perversely become a source of pride.

Second, shaming penalties may be disproportionately too strong. If shame may not work at all on some offenders, it may work all too well on others. Shame is, or can be, a powerful emotion largely because its impact encompasses the self as a whole. ${ }^{76}$ At the extreme, shame can result in self-destruction as the subject of shame tries to rid himself of it through suicide. ${ }^{77}$ Of course, less extreme responses like exiting from (and so hiding from the view of) the community are also possible and probably more likely. Still, where shame "works," it may impose hardships no one thinks the shamed offender really deserves. ${ }^{78}$

According to Kahan, however, this approach to proportionality asks too much. ${ }^{79}$ Shaming penalties cannot fairly be assessed by whether or not, and to what extent, any particular offender suffers the emotional experience of shame.. After all, other criminal sanctions such as imprisonment exact a difficult-to-predict psychological and emotional toll that varies from one offender to

${ }^{76}$ See, for example, Taylor, Pride, Shame and Guilt at 89 (cited in note 25). One pair of writers characterized shame "in the wrong hands" as the "nitroglycerin of emotions." Jonathan Alter and Pat Wingert, The Return of Shame, Newsweek 21 (Feb 6, 1995).

"See, for example, Persons, Note, 49 Vand L Rev at 1527 (cited in note 12) (reporting one man who committed suicide after his name was published for soliciting a prostitute); Woolner, Am Law at 35 (cited in note 9) (reporting case of a young man who committed suicide when his mother found out about his DUI conviction). Of course, prison inmates also commit suicide. See, for example, David Lester and Bruce L. Danto, Suicide Behind Bars: Prediction and Prevention 24 (Charles 1993) (describing the profile of the "typical suicidal inmate" in "police lockups" as one who kills himself because, among other things, he "feels embarrassed, especially over the impact his arrest will have on his family").

${ }^{73}$ Compounding this difficulty is the problem of spillover. For example, if an offender has a family, some of the shame he accrues may spill over onto his family members, who may unfairly be subject to the community's scorn. See, for example, von Hirsch, Censure at 86-87 (cited in note 64) (noting that noncustodial penalties may have greater potential for third party impact than imprisonment). When a husband's face appears on the local cable access channel for soliciting a prostitute, it may be his wife and children who suffer most. See, for example, Richard H. Pildes, The Destruction of Social Capital Through Law, 144 U Pa L Rev 2055, 2075 (1996) (describing an Ohio case where publishing the name of a man caught soliciting a prostitute caused even greater public humiliation for his wife), citing John Hopkins, Publishing Names of 'Johns' Punishes Families, Wife Says, Cin Enq B1 (Apr 18, 1996); Woolner, Am Law at 35 (cited in note 9) (concluding that the "problem with shaming is that its hard to judge the side-effects"). However, if shaming penalties are imposed on offenders who would otherwise go to prison, the spillover effects of shame may be no greater than those of imprisonment. Compare Massaro, 89 Mich L Rev at 1938 (cited in note 41) (suggesting that "[e]xpanded use of public shaming surely would deliver more convincing blows" to third parties than conventional punishment).

${ }^{79}$ See Kahan, 63 U Chi L Rev at 636-37 (cited in note 31). 
the next. ${ }^{80}$ But these differential effects are not ordinarily thought to render imprisonment problematic on proportionality grounds.

Rather than gauging proportionality by the emotional reactions of individual offenders, Kahan argues that it should be gauged by the social meaning of the sanction-i.e., by its ability to express, and the degree to which it expresses, moral condemnation. Because expressive meaning is a social phenomenon, it can be evaluated without taking into account a particular offender's psychological propensity to experience shame. ${ }^{81}$ While not as easy to measure as dollars or time, getting a handle on social meaning may nonetheless be easier than guessing the emotional and psychological effects of a particular sanction on a particular offender. Feeling shame is one thing. Being shamed is another. Shame's defenders insist proportionality analysis should focus on meanings and not feelings.

All the same, shame presents a major challenge to retributivist notions of proportionality. Comparing one offense to another and ranking them from top to bottom in order to fix the moral seriousness side of the proportionality equation is hard enough. Adding shame to the mix of possible punishments introduces variability and complexity to the severity side of the equation that at least some retributivists will want to avoid. ${ }^{82}$

\section{Deterrence.}

In theory, it makes perfect sense to think that shame can be an effective deterrent, both specifically and generally. Criminal sanctions can forestall future wrongdoing either (in the language of economic analysts) by raising the cost of committing the offense (specific and general deterrence), or by inducing a change in the potential offender's preference, or "taste," for crime. ${ }^{83}$ The former effect is direct. The latter, often referred to as the "moralizing" influence of the criminal law, ${ }^{84}$ is indirect and more diffuse.

${ }^{80}$ This is especially true of offenders with high reputations to lose. See, for example, Sol Wachtler, After the Madness: A Judge's Own Prison Memoir (Random House 1997) (memoir of former chief judge of the New York Court of Appeals, who was convicted of harassment).

${ }^{81}$ See Kahan, 63 U Chi L Rev at 648 (cited in note 31). Compare Massaro, 89 Mich I Rev at 1939 (cited in note 41) ("The 'cultural meaning of shame' is exceedingly amorphous, if indeed one national meaning exists.").

82 See von Hirsch, Censure at 62 (cited in note 64) ("The more numerous . . . sanctions are the more difficult and elusive the task of comparing severity becomes."). Retributivists object to educating penalties on the same grounds. See note 238 .

${ }^{83}$ See, for example, Kahan, 63 U Chi L Rev at 638-39 (cited in note 31).

${ }^{84}$ See Johannes Andenaes, The General Preventive Effects of Punishment, $114 \mathrm{U} \mathrm{Pa} \mathrm{L}$ 
The former effect tends to make a criminal offense unattractive, while the latter tends to make it unthinkable.

More specifically, publicity and its potentially attendant shame can deter wrongdoing in three ways. ${ }^{85}$ First, they impose, although to a comparatively limited or even trivial degree, some limitation on the offender's freedom. He must, for example, stand in public wearing a sign or abide by some similar restriction. Second, and more importantly, they produce (if they work) an unpleasant emotional experience for the offender, which potential offenders will want to avoid and actual offenders will want to avoid repeating. ${ }^{86}$ Third, depending on the nature of his commu-

Rev 949, 950 (1966) ('The 'messages' sent by law . . . contain factual information about what would be risked by disobedience, but they also contain proclamations specifying that it is wrong to disobey."); Gordon Hawkins, Punishment and Deterrence: The Educative, Moralizing, and Habituative Effects, 1969 Wis L Rev 550, 555 ("[P]unishment is a ritualistic device designed to influence persons by intimating symbolically social disapproval and society's moral condemnation.”). See also Franklin E. Zimring and Gordon J. Hawkins, Deterrence: The Legal Threat in Crime Control 77-89 (Chicago 1973) (discussing the educative moral effect of criminal sanctions); Ronald L. Akers, Rational Choice, Deterrence, and Social Learning Theory in Criminology: The Path Not Taken, 81 J Crim L \& Criminol 653, 655 (1990) (arguing that both effects are "subsumable under the more general differential reinforcement formula in social learning theory"); Kenneth G. Dau-Schmidt, An Economic Analysis of the Criminal Law as a Preference-Shaping Policy, 1990 Duke L J 1, 14-22 (providing an economic analysis of the criminal law's moralizing influence).

For empirical assessments of this effect, see, for example, Nigel Walker and Catherine Marsh, Do Sentences Affect Public Disapproval, 24 Brit J Criminol 27, 41 (1984) (finding that "peers' views and 'criminalisation' could, in some circumstances, affect disapproval" but that "information about the sentence or about judicial disapproval" does not); Nigel Walker and Michael Argyle, Does the Law Affect Moral Judgments?, 4 Brit J Criminol 570, 579 (1964) (finding "no significant differences . . . between those who were told that a given type of conduct was a criminal offense and those who were told it was not").

${ }^{\text {ss }}$ See Harold G. Grasmick and Donald E. Green, Legal Punishment, Social Disapproval and Internalization as Inhibitors of Illegal Behavior, $71 \mathrm{~J}$ Crim L \& Criminol 325, 334 (1980) (discussing an empirical study finding that legal sanctions, social disapproval, and moral commitment can explain about 40 percent of the variance in variables used to measure "illegal behavior").

see Harold G. Grasmick and Robert J. Bursik, Jr., Conscience, Significant Others, and Rational Choice: Extending the Deterrence Model, 24 L \& Society Rev 837, 853-54 (1990) (discussing an empirical study finding "strong evidence of a deterrent effect of shame" with respect to tax cheating, theft, and drunk driving). See also Harold G. Grasmick, Robert J. Bursik, Jr., and Karyl A. Kinsey, Shame and Embarrassment as Deterrents to Noncompliance with the Law: The Case of an Antilittering Campaign, 23 Envir \& Beh 233, 248 (1991) (discussing an empirical study of antilittering campaign and concluding that "threats of shame and embarrassment significantly reduced the reported inclination to litter"); Stephen G. Tibbets, Shame and Rational Choice in Offending Decisions, 24 Crim Just \& Beh 234, 245 (1997) (discussing an empirical study finding that "[s]hame states due to exposure had negative effect on intentions to shoplift but had no significant effect on intentions to drive drunk" and that "shame states without exposure had inhibitory effects on intentions to commit both offenses"). But see Harold G. Grasmick, et al, Changes in Perceived Threats of Shame, Embarrassment, and Legal Sanctions for Interpersonal Violence, 1982-1992, 8 Violence \& Victims 313, 323 (1993) (discussing an empirical study concluding that "respondents in 1992 experience[d] no greater pain of 
nal attachments, he may suffer adverse consequences from members of the community, who may gossip about him or refuse to engage in various forms of social and economic intercourse with him. ${ }^{87}$ If shaming penalties can successfully impose all these costs, they should in principle make effective deterrents. ${ }^{88}$ Add to this the moralizing effects of widespread publicity of offenders' wrongdoing, and shame promises to be a useful ally on the side of order-and, compared to imprisonment, a cheaper ally, too.

Doubts about the deterrent power of shame track those related to shame and proportionality. As for specific deterrence, when shame does work, it may ironically push an offender into greater criminality. Rather than simply shame him, the penalty may "stigmatize" or "label" him a "criminal." And if an offender comes to identify himself as a "criminal," the result may be more crime, since crime is what "criminals" do. Of course, the stigmatizing effect of shaming penalties may be no more dramatic than those of a stint, however short, in prison. ${ }^{90}$ Conversely, when shaming doesn't work, it may be because the offender is so socially alienated and disaffected that he is already at risk of engaging in criminal activity. Under these circumstances the deter-

shame or remorse for physically hurting someone on purpose than did respondents in 1982”).

${ }^{87}$ See Eric Rasmusen, Stigma and Self-Fulfilling Expectations of Criminality, $39 \mathrm{~J} \mathrm{~L}$ \& Econ 519, 540 (1996) (concluding that "[g]overnment stigmatization is extremely important, but its purpose is really to provide the private sector with the raw materials for a more efficient way of dealing with offenders").

Shaming penalties also may reduce crime insofar as they increase private monitoring of an offender; that is, third parties who would suffer spillover stigma from the publication of his wrongdoing, such as family members, may work harder to keep him in line. See, for example, Kahan, 63 U Chi L Rev at 643 n 215 (cited in note 31).

See Edwin M. Lemert, Social Pathology 318-19 (McGraw-Hill 1951) (discussing sociological notion of "secondary deviance"); Charles R. Tittle, Sanctions and Social Deviance: The Question of Deterrence 177-78 (Praeger 1980) (discussing "labeling" or "societal reaction theory); David $\mathrm{A}$. Ward and Charles $\mathrm{R}$. Tittle, deterrence or labeling: the effects of informal sanctions, 14 Deviant Beh 43, 44-45 (1991) (discussing "labeling approach"). See also David R. Karp, The Judicial and Judicious Use of Shame Penalties, 44 Crime \& Delinquency 277, 284 (1998) ("The result of this shaming process is labeling and, worse, exclusion from the community."); Posner, Shaming Penalties at 13-14 (cited in note 56) (arguing that shaming penalties can create "deviant subcommunities").

${ }^{90}$ See Kahan, $63 \mathrm{U}$ Chi L Rev at 645 (cited in note 31). The problem of stigmatization might, as Kahan suggests, be ameliorated if shaming rituals were accompanied by "reintegration" rituals, i.e., rituals that formally "restore status to the offender after marking his conduct as deviant." Id. See also John Braithwaite, Crime, Shame and Reintegration 55 (Cambridge 1989) (arguing that "stigmatization," unlike "reintegrative shaming," "divides the community by creating a class of outcasts"); John Braithwaite and Stephen Mugford, Conditions of Successful Reintegration Ceremonies: Dealing with Juvenile Offenders, 34 Brit J Criminol 139, 143 (1994) (identifying fourteen conditions of successful "reintegration ceremonies"). Extant shaming penalties typically lack such rituals. See Massaro, 3 Psych, Pub Pol, \& L at 694 (cited in note 30). 
rent impact of shame may be negligible. ${ }^{91}$ In reality, however, the number of such completely disaffected and therefore shameless people is probably smaller than one might think. ${ }^{92}$

As for general deterrence, much depends on the nature of the relevant community. At one extreme, a community may be so atomized that no one cares very much about what anyone thinks of anyone else, in which case that particular association of persons hardly deserves to be called a community in the first place. ${ }^{93}$ Shame is unlikely to play a significant role in the social life of so thin an association. At the other extreme, the self may be unable to conceive of itself independent of its attachments to the community ${ }^{94}$ in which case shame may be a powerful regulator in social life, squeezing out the need for any legal regulation or formal sanctions altogether. ${ }^{95}$ The truth lies somewhere in between and varies from community to community. All else being equal, however, shaming penalties are likely to be more effective in Kenosha than they are in Manhattan. This is not to say they will be wholly ineffective in Manhattan, ${ }^{96}$ only that we should expect less.

All of this is highly speculative. Some judges who regularly impose shaming penalties insist that it deters just as well as, if not better than, the alternative sanction, ${ }^{97}$ which usually means prison. Still, no one knows for certain. Shaming penalties are too new, and, as Kahan says, no one has yet subjected them to sys-

"1 See, for example, Karp, 44 Crime \& Delinquency at 291 ("[B]ecause shaming is predicated on the offender's stake in conventional society, it is not likely to be effective for individuals already on the margins."). The risk of underdeterrence could, of course, be addressed by combining shame with other sanctions, including short stints of imprisonment. See Kahan, $63 \mathrm{U}$ Chi L Rev at 641 (cited in note 31).

"2 See John Braithwaite, Shame and Modernity, 33 Brit J Criminol 1, 2 (1993) (arguing that the "nature of interdependencies in modern urban social relations can actually increase rather than decrease our exposure to shame").

* In fact, the decline of shaming penalties in colonial America has been attributed to increasing doubts about their power to deter, which in turn is usually attributed to the weakening of communal ties associated with the colonies' increasing, and increasingly mobile, population. See, for example, Hirsch, Rise of the Penitentiary at 38 (cited in note 5) ("[T] with whom offenders were unacquainted, and with whom they need have no further personal contact.").

" See Michael J. Sandel, Liberalism and the Limits of Justice 150 (Cambridge 1982) (describing this "communitarian" conception of the self).

${ }^{*}$ See, for example, Massaro, 89 Mich L Rev at 1904-17 (cited in note 41) (examining cultures that rely heavily on informal sanctions).

* For example, imagine Leona Helmsley in stocks in Central Park for tax evasion. See Mona Charen, For the Likes of Helmsley, The Stocks, Newsday 46 (Dec 18, 1989) (making this suggestion).

${ }^{77}$ See, for example, Ted Poe, Public Humiliation is Effective Deterrent, Dallas Morning News 31A (Apr 11, 1997) (statement by major judicial practitioner of shaming penalties on their effectiveness). 
tematic empirical inquiry. ${ }^{98}$ The most one can say for now is that shaming penalties can deter some offenders some of the time, ${ }^{99}$ even if they don't deter optimally. ${ }^{100}$ Under the right circumstances, for example, posting the phone numbers and names of slumlords outside their below-code properties can probably be a very effective way to enlist the deterrent (and remedial) power of shame. ${ }^{101}$ Similarly, some communities that publicize the names of men who solicit prostitutes report that the number of prostitutes on the city's streets declined noticeably, ${ }^{102}$ although these reports are mixed. ${ }^{103}$

\section{Rehabilitation.}

Although it has fallen from favor, ${ }^{104}$ rehabilitation remains among the traditional justifications for punishment, and the possibility that shame can rehabilitate has been noted as a source of its appeal. ${ }^{105}$ The courts, however, have searched in vain for

${ }^{83}$ Kahan, 63 U Chi L Rev at 638 (cited in note 31).

${ }^{\infty}$ See, for example, Massaro, 3 Psych, Pub Pol, \& L at 695 (cited in note 30) (“[I]t would be silly [to suggest] . . . that properly crafted, context-sensitive shame penalties can't ever deter misconduct in any modern context."); Whitman, 107 Yale L J at 1068 (cited in note 49) ("Shame sanctions are likely to work in the ways in which they are applied, even in a modern, western, urban society.").

${ }^{100}$ See Posner, Shaming Penalties at 2 (cited in note 56) (" $[S]$ haming penalties are likely to produce arbitrary levels of punishment ... resulting in arbitrary levels of deterrence.").

${ }^{101}$ See, for example, Eveld, Shame makes a comeback, Kan City Star at A1 (cited in note 14) (reporting that, of four landlords threatened with a shaming sign, two fixed their property immediately, and the other two fixed their property soon after signs went up on another landlord's property); Larrabee, Fighting crime, USA Today at 3A (cited in note 12) (reporting similar success in Framingham, Massachusetts).

${ }^{102}$ See Kahan, 63 U Chi L Rev at 640 (cited in note 31) (noting that La Mesa, California officials report fewer prostitutes on the streets since the city began publishing the names of patrons). See also Timothy Heider, 'John TV' credited with cutting crimes, Kan City Star C12 (Nov 28, 1997) (noting that solicitation has dropped by one-third since the show aired in May); Phil Garlington, 'John TV' helps merchants sweep strip, Orange County Reg A37 (Oct 12, 1997) (quoting Stockton police spokesman as saying "our anecdotal report from officers is that the number of prostitutes on the street has dropped off").

${ }^{103}$ See, for example, Persons, Note, 49 Vand L Rev at 1543 \& n 95 (cited in note 12) (citing examples of the ineffectiveness of shaming).

${ }^{10}$ See generally Francis A. Allen, The Decline of the Rehabilitative Ideal: Penal Policy and Social Purpose 1-2 (Yale 1981) (noting that "[i]n the course of a decade, perhaps less, the rehabilitative ideal suffered a precipitous decline in its capacity to influence American penal practice").

${ }^{10 x}$ See Massaro, 89 Mich L Rev at 1895 (cited in note 41) ("Shaming therefore can be justified under rehabilitation theory, provided that the evidence, which is not yet available, bears out that this 'rehabilitation' in fact influences behavior."); Whitman, 107 Yale I $J$ at 1067-68 (cited in note 49) (noting that shame may work on first-time offenders as "liminal rites, rites that warn first and minor offenders that they are flirting with a deep, and deeply undesirable, status change"). 
shame's rehabilitative potential. ${ }^{106}$

For example, in one recent case, People $v$ Meyer, ${ }^{107}$ the Illinois Supreme Court rejected the shaming sanction imposed on Glenn Meyer, who had been convicted of aggravated battery. ${ }^{108}$ The trial court sentenced Meyer to thirty months probation, and among other things, required him to post a large sign at the entry to his property stating, "Warning! A Violent Felon lives here. Enter at your own risk."109 Although the court recognized that the sign might punish Meyer, and might put anyone who entered his property on notice that he could be dangerous, Illinois's law required probation conditions to serve some plausible rehabilitative function, which according to the court, the sign did not. ${ }^{110}$

The Illinois court was following the lead of courts in Tennessee and New York. In State $v$ Burdin, ${ }^{111}$ the Tennessee Supreme Court also found shame and rehabilitation to be at odds. Wayne Burdin had pled guilty to sexual battery. ${ }^{112}$ The trial court suspended Burdin's one-year sentence and placed him on two years of probation, with the condition that he place in his front yard a "four-by-eight foot sign with black letters over a yellow background stating: Warning, all children. Wayne Burdin is an admitted and convicted child molester." ${ }^{m 13}$ However, according to the Tennessee Supreme Court, the purpose of a probationary sentence was rehabilitation. ${ }^{114}$ Because the court was skeptical of the rehabilitative potential in requiring Burdin to announce his offense on a sign in his front yard, the court held the sentence to be invalid. ${ }^{115}$

${ }^{100}$ When shaming penalties are imposed as a condition of probation, they frequently escape judicial review. Because the offender agrees to the condition, he usually makes no effort to challenge it on appeal. See Neil P. Cohen and James J. Gobert, The Law of Probation and Parole $\$ 5.08$ at 207-08 (Shepard's 1983) ("Since most offenders are delighted to receive probation or parole and have agreed to, or at least acquiesced in, the conditions imposed, they rarely litigate the validity of the conditions.").

${ }^{107} 186$ Ill 2d 372, 680 NE2d 315 (1997).

${ }^{108} \mathrm{Id}$ at 320 .

${ }^{100}$ Id at 316 .

${ }^{110}$ Id at 320 (holding the punishment of posting the sign to be inconsistent with probation statute insofar as it was designed to humiliate rather than rehabilitate the offender). The court also invalidated the condition on the ground that the "sign may have unpredictable or unintended consequences which may be inconsistent with the rehabilitative purpose of probation." Id.

"'1 924 SW2d 82 (Tenn 1996).

${ }^{112}$ Id at 83-84.

${ }^{113}$ Id at 84. Although Burdin "essentially stood mute" when the court imposed the condition, he objected to it on appeal. The Tennessee Supreme Court entertained his objection, despite the fact he did not object during sentencing, under a Tennessee procedural rule allowing it to review any error "at any time where necessary to do justice." Id.

${ }^{11}$ Id at 86 ("The primary goal of probation ... . is the rehabilitation of the defendant.").

${ }^{115}$ Id at 87. 
The New York Court of Appeals reached a similar conclusion. ${ }^{116}$ Roy Letterlough pled guilty to driving while under the influence, his sixth alcohol-related driving offense in the last twenty years. ${ }^{117}$ As part of a plea agreement, his license was revoked, and he was sentenced to five years of probation. ${ }^{118}$ If, however, the Department of Motor Vehicles decided to restore his license at any time during the probationary period, Letterlough was required to put on his car a fluorescent sign that read, "CONVICTED DWI." Describing the "overriding purpose" of probation to be the offender's rehabilitation, ${ }^{120}$ and finding that the sign was punitive, not rehabilitative, the New York Court of Appeals invalidated the condition. ${ }^{121}$

Not all courts see things this way. The Florida intermediate courts, for example, have looked more favorably upon modern-day scarlet letters. The reasoning of the Florida courts, however, rests on a simple confusion. In Goldschmitt $v$ State ${ }^{122}$ Goldschmitt had been convicted of DUI, and, like Letterlough in New York, had been required to post a "CONVICTED D.U.I.-RESTRICTED LICENSE" sign on his car. ${ }^{123}$ The court upheld the condition, reasoning that the "deterrent, and thus the rehabilitative, effect of punishment may be heightened if it inflicts disgrace and contumely in a dramatic and spectacular fashion, ${ }^{2124}$ which it thought the sign did. ${ }^{125}$

${ }^{118}$ See People $v$ Letterlough, 86 NY2d 259, 655 NE2d 146, 146 (1995).

${ }^{117}$ Id at 147.

${ }^{118} \mathrm{Id}$.

${ }^{119}$ Id. The sign was also easily removable, thereby reducing some of the spillover stigma. See id. The defendant's failure to object to the condition did not prevent the appellate court from reviewing the condition, because it "involve[d] the essential nature of the right to be sentenced as provided by law." Id at $148 \mathrm{n} 1$ (citation and internal quotation marks omitted).

${ }^{120}$ Id at 148.

${ }^{121}$ Id at 151 ("[T]he 'convicted dwi' sign . . . cannot under any view be regarded as a rehabilitative measure authorized by [the state's] Penal Law."). The court also noted that, if preventing an offender from driving while intoxicated was the aim of the condition, requiring an "ignition interlock device" plausibly could accomplish that end without shame. Id.

${ }^{122} 490$ S2d 123 (Fla Dist Ct App 1986).

${ }^{123}$ Id at 124 .

${ }^{124}$ Id at 125 (emphasis added), quoting United States $v$ William Anderson Co, Inc, 698 F2d 911, 913 (8th Cir 1983). See also Lindsay v State, 606 S2d 652, 656 (Fla Dist Ct App 1992). The Florida Supreme Court has yet to review shaming penalties.

The Georgia courts also have approved shaming penalties. See Ballenger $v$ State, 436 SE2d 793, 794 (Ga Ct App 1993) (upholding probation condition requiring DUI offender to wear a "fluorescent pink bracelet imprinted with the words 'D.U.I. CONVICT"). The Ballenger court, like the Goldschmitt court, elided the distinction between rehabilitation and specific deterrence. See id at 794-95.

${ }^{125}$ See Goldschmitt, 490 S2d at 126. 
But this reasoning confuses specific deterrence and rehabilitation. The difference between the two, which the Florida court ignored, turns not on whether a particular sanction can stop an offender from offending again in the future, but why he refrains from offending. Specific deterrence forestalls future offenses by changing the offender's cost-benefit calculus. Rehabilitation, on the other hand, forestalls future offenses by changing the defendant's preferences. The specifically deterred offender now knows what it feels like to be punished, and out of fear, avoids making the same mistake twice. The rehabilitated offender, in contrast, now knows and accepts that what he did was wrong, and out of respect for the law and the rights of others, no longer thinks it is morally tolerable to violate either of them. The distinction can be elusive, but it is important nonetheless.

Shaming penalties can specifically deter, but, as the courts of New York and Illinois have recognized, their power to rehabilitate is more questionable. Insofar as a particular offender is "shame-able," he will, having once experienced that unpleasant emotion, fear experiencing it again and so might refrain from future wrongdoing. If this is "rehabilitation," it is rehabilitation in the most minimal sense and really amounts to nothing more than "Pavlovian conditioning."

\section{Is Shame Undignified?}

Despite the difficulties shaming penalties face on retributivist, deterrence, and rehabilitative grounds, even critics of shame seem hard-pressed to dismiss such penalties entirely on those grounds alone. ${ }^{127}$ Another objection, however, questions whether shame respects the limits that any morally respectable punishment should respect. Yet, here too, the answer is unclear.

1. Dignity.

Shaming penalties are, for example, said to be cruel, degrading, demeaning, humiliating, or otherwise generally inhumane. ${ }^{128}$ At some point, these objections blur together. At the risk

${ }^{125}$ Goldschmitt, 490 S2d at 125-26.

${ }^{127}$ See, for example, Massaro, 89 Mich L Rev at 1900 (cited in note 41) ("The traditional theories of punishment suggest that all of the shaming sanctions can be justified under one or several of the basic theories.").

${ }^{123}$ See, for example, Massaro, 3 Psych, Pub Pol, \& I at 703 (cited in note 30) ("[P]sychological works on shame ... analyze closely how shaming may convey contempt, and result in humiliation rather than shame."); Massaro, 89 Mich L Rev at 1936-43 (cited in note 41) (arguing that shaming penalties are especially likely to violate "humaneness factors"). 
of oversimplification, we can perhaps safely reduce them to the basic idea that shaming penalties violate an offender's dignity, which no morally decent state should do. ${ }^{129}$

But figuring out just what limits dignity places on punishment is not easy. All forms of punishment are to some degree degrading. ${ }^{130}$ How else could they convey their condemnatory message? Perhaps the most we can say is that morally respectable forms of punishment maintain a delicate balance between legitimate condemnation and illegitimate degradation. ${ }^{131}$ Torture plainly falls on the degrading side of the line, but where shaming penalties fall is harder to say.

According to Toni Massaro, a powerful critic of shaming penalties, "[s]tate-enforced shaming authorizes public officials to search for and destroy or damage an offender's dignity." ${ }^{\text {132 }}$ According to Andrew von Hirsch, a proponent of "just deserts" but an opponent of shame, the stocks and pillory may be the classic examples of illegitimate "demeaning rituals," but forcing offenders to "attach self-accusing bumper-stickers to their vehicles" and other forms of "compulsory attitudinalizing" should also be ruled out on grounds of dignity. ${ }^{133}$

In a recent and exceptionally thoughtful essay, James Whitman tries to pinpoint exactly what is wrong with imposing shame sanctions. According to Whitman, shaming sanctions risk "nudg[ing] prevailing public views in a new, and more moralistic direction," tend to transform the public into a "mob, or collection of petty private prison guards," and involve a "troubling tolerance for ochlocracy [that is, government by mob], for a democratic government too susceptible to the pitch and yaw of mob psychology." Whitman, 107 Yale L $J$ at 1089 (cited in note 49). Together, these effects threaten what Whitman calls an offender's "transactional dignity," which he describes as a "deeply rooted norm of our society that persons should never be forced to deal with wild or unpredictable partners." Id at 1090.

${ }^{120}$ See Avishai Margalit, The Decent Society 262 (Harvard 1996) (Naomi Goldblum, trans) (" $[\mathrm{A}]$ society is a decent one if it punishes its criminals-even the worst of themwithout humiliating them."). See also Trop $v$ Dulles, 356 US 86, 100 (1957) (describing the Eighth Amendment's ban on cruel and unusual punishments as resting on "nothing less than the dignity of man").

${ }^{130}$ Indeed, the entire criminal process can be understood as a series of "status degradation ceremonies." See Braithwaite and Mugford, 34 Brit J Criminol at 141 (cited in note 90) ("Most criminal trials are good examples of status degradation ceremonies."); Joseph Goldstein, Police Discretion Not To Invoke the Criminal Process: Low-Visibility Decisions in the Administration of Justice, 69 Yale L J 543, 590 (1960) (The criminal process, from arrest through release, is comprised of a series of "status degradation ceremonies.").

${ }^{131}$ See Hampton, Expressive Theory at 14 (cited in note 33) ("Hence the construction of retributive punishment is an art, which involves the satisfaction of two demands: first, that the wrongdoer be diminished; and second, that the diminishment not represent him as lower in value than the victim."); von Hirsch, Censure at 82 (cited in note 64) ("The answer lies in the difference between censure and attempts to humiliate.").

${ }^{132}$ Massaro, 89 Mich L Rev at 1943 (cited in note 41).

${ }^{123}$ See von Hirsch, Censure at 83 (cited in note 64). 
Defenders of shaming penalties, including Kahan, recognize the risk such sanctions pose for human dignity and the need for some limits. They don't urge a wholesale return to the full panoply of colonial punishments. Public whipping, for example, is out of the question. ${ }^{134}$ Nor do they urge municipalities to invest in the construction of public stocks and pillories reminiscent of puritan Massachusetts. ${ }^{135}$

Still, I think that some contemporary shaming penalties do cross - or come close to crossing - the line. For example, fed up with juvenile delinquency, the town of Dermott, Arkansas passed a city ordinance under which the parents of delinquents would be "placed within stockaded public display six hours a day," though not for more than "two consecutive days." count, public display within a stockade would come close to, if not step over, the line, as would forcing an offender who was "acting like a baby" to wear a diaper over his regular clothing. ${ }^{137}$

But shame's defenders endorse more modest measures, like signs, newspaper advertisements, public speeches, and public apologies. Whether these forms of shame go too far is debatable.

${ }^{13}$ See Kahan, 63 U Chi L Rev at 617 (cited in note 31) (arguing that corporal punishment is politically unacceptable because the message it conveys is that "offenders are the natural or social inferiors of those who discipline them"). Compare Graeme Newman, Just and Painful: A Case for the Corporal Punishment of Criminals 41-49 (Macmillan 2d ed 1995) (arguing that corporal punishment in the form of graduated electric shocks is the "fairest punishment of all"); Kan, $25 \mathrm{~J}$ Legal Stud at 130 (cited in note 21) (advocating use of electric shock to incapacitate "offending organs").

${ }^{133}$ Such devices might be held unconstitutional today. See Goldschmitt, $490 \mathrm{~S} 2 \mathrm{~d}$ at 125 (indicating that pillory would be cruel and unusual punishment but distinguishing DWI bumper sticker from the "degrading physical rigors of the pillory"), citing Hobbs $v$ State, 133 Ind 404, 32 NE 1019, 1021 (1893) ('Cruel' ... meant . . . such as that inflicted at the whipping post, in the pillory, breaking on the wheel, etc."); State v Moilen, 140 Minn 112, $167 \mathrm{NW} 345,346$ (1918) (finding that the legislature decides penalties and that they "must stand however harsh it may seem to those who run counter to its commands"); State $v$ Gedicke, 43 NJL 86, 96 (NJ Sup Ct 1881) (holding that it was not cruel and unusual punishment to impose both a fine and imprisonment).

Imagine, however, a modern-day pillory located near the local courthouse in which the openings for the arms and head were fully padded and in which the offender was required to spend only an hour at high noon. Imagine also that a canvas awning shades the offender from the sun and a plexiglass screen protects him from any possible projectiles launched by the crowd or passers-by. Would such a modified pillory materially differ from requiring an offender to stand on the courthouse steps for the same period of time wearing a sandwich-board that announced his crime?

${ }^{136}$ Not surprisingly, the stockade was never built. See Suzanne Fields, Going After the Parents, Wash Times F1 (Aug 15, 1989); Resurrecting the Stockade: Town plans to use public shame to fight lawlessness, St. Petersburg Times 3A (Aug 9, 1989); Town Beset By Delinquents Moves to Pillory Parents, The Record A18 (Aug 13, 1989).

${ }^{137}$ See Bienz v State, 343 S2d 913, 914-15 (Fla 1977) (holding that an order issued by halfway house "therapist coordinator" that probationer "wear diapers on the outside of his pants" would be "demeaning" in the "minds of ... reasonable men" and the violation thereof could not form basis for revoking probation). 
Moreover, shame's defenders make a powerful comparative point: If the alternative to shame is imprisonment, then at worst, shame simply substitutes one set of indignities for another. ${ }^{138}$ And, at best, shame saves offenders from a far greater indignity. Indeed, perhaps the only saving grace of prison's indignities is that the rest of us need not bear witness.

Comparing the indignity of prison with that of shaming penalties is complicated, however, because the social meaning of prison is ambiguous. On the one hand, prison means the deprivation of liberty. ${ }^{139}$ Inmates are intentionally subjected to a daily routine not of their own choosing, and they lack many of the basic liberties the rest of us take for granted. If this abstract account is what we have in mind when we talk about imprisonment, then it makes sense to claim, as some do, that "a person can endure the deprivation of . . . liberties with dignity."140 With this mild vision in mind, perhaps imprisonment is better than shame at honoring dignity.

For Kahan, however, this vision is Pollyanish. ${ }^{141}$ Imprisonment, we all know, typically includes deprivations that extend far beyond the simple deprivation of liberty. The grimy and sometimes harsh living conditions, ${ }^{142}$ along with the omnipresent risk of violence, ${ }^{143}$ all too often represent the reality-and indignityof daily life in prison. The benign phrase "deprivation of liberty" looks much less respectful of human dignity if the image we have in mind is one of inmates "caged like animals." From this Realpolitik perspective, evaluating which is more "undignified"prison or public shaming-will depend on the details. A week's stay in some local county jails or minimum security facilities may be more dignified than standing for two hours on the courthouse steps for several days in a row wearing a sign describing one's offense. On the other hand, time in a maximum security state prison, no matter how short, may make that same two hour stint look benign by comparison.

\footnotetext{
${ }^{139}$ See Kahan, 63 U Chi L Rev at 646 (cited in note 31) ("II]mprisonment . . . adds a grotesque variety of indignities shaming cannot hope to rival.").

${ }^{139} \mathrm{See}$, for example, von Hirsch, Censure at 84 (cited in note 64) ("Imprisonment should be imposed as punishment but not for punishment.").

${ }^{160}$ Id at 82.

${ }^{14}$ See Kahan, $63 \mathrm{U}$ Chi L Rev at 646-49 (cited in note 31).

${ }^{142}$ See Norval Morris, The Contemporary Prison 1965-Present, in Norval Morris and David J. Rothman, eds, The Oxford History of the Prison 249 (Oxford 1995).

${ }^{14}$ See generally Michael C. Braswell, Reid Montgomery, and Lucien X. Lomardo, eds, Prison Violence in America (Anderson 2d ed 1994) (analyzing different dimensions of prison violence).
} 
But shame's proponents have a strategy that allows them to bypass complicated and controversial debates about the nature of human dignity, and the comparative indignities of prison and shame. The basic strategy, examined below, relies on the normative power of consent.

\section{Consent.}

Shaming penalties are seldom imposed as independent, freestanding sanctions. Instead, they are usually imposed as a "special" condition of probation or a suspended sentence. Consequently, most offenders subject to shaming penalties usually agree to them in order to get probation. ${ }^{144}$ If so, how can anyone complain?

From the offender's perspective, shame is plainly the lesser of two evils. Consent, so the argument goes, pulls the rug out from under dignity-based objections to shame. ${ }^{145}$ After all, isn't free will, the source of our power to consent, one of the foundations of human dignity, even if human dignity is not reducible to consent? ${ }^{146}$ If so, then shame's defenders can fight fire with fire, drawing on one strand of dignity to offset objections based on another.

But this strategy raises a problem. Consent is valid only if it is uncoerced. But in order to know whether or not consent is coerced, we need to know the relevant baseline. That is, what's the alternative to the "chosen" option? Offenders who elect shame usually do so because the baseline-what they will get if they refuse to accept shame-is in fact imprisonment. From this perspective, shame looks like an offer most offenders would be silly to refuse. Indeed, most offenders don't refuse. ${ }^{147}$ Most take the shame. $^{148}$

im Of course, not all shaming penalties are based on consent. In Pennsylvania, for example, courts are required to publish the name and sentence of anyone twice convicted of soliciting a prostitute "in a newspaper of general circulation in the judicial district in which the court sits." See 18 Pa Cons Stat Ann $\$$ 5902(e)(2) (Purdon 1996).

${ }^{14}$ See Kahan, 63 U Chi I Rev at 647 (cited in note 31) ("[I]t is . . e either confused or disingenuous ... to say that one of the reasons to disregard offenders' [choice of shame over prison] is to spare them from cruelty."). But see Massaro, 3 Psych, Pub Pol, \& L at 699 (cited in note 30 ) ("[O]ne may read the choice of shaming over prison as evidence that both are horrible prospects, but that prison imposes the double cost of stigma and liberty deprivation. Shaming does look bad; it's just that prison looks worse."). Compare von Hirsch, Censure at 81 (cited in note 64) (arguing that "a penal measure needs to be justified in its own right, not merely by comparison with another, possibly worse measure").

${ }^{1+8}$ See R. George Wright, Consenting Adults: The Problem of Enhancing Dignity NonCoercively, 75 BU L Rev 1397, 1398 (1995) ("Making legal rights and duties contingent on consent usually serves human dignity.").

${ }^{147}$ See Kahan, $63 \mathrm{U}$ Chi L Rev at 641 (cited in note 31) ("[O]ffenders typically opt for 
However, this approach to the issue of consent relies on the status quo to fix the baseline. ${ }^{149}$ But why should that be so? Why isn't some "lesser" sanction the appropriate baseline? For example, if the punishment for an offender who "consents" to shame should be straight probation and not imprisonment then what looks like an offer is in fact a threat, and the offender's consent to shame is coerced and thus invalid. In order for consent to constitute a full defense of shame, what's needed is an argument that imprisonment is the morally appropriate default option. Proponents of shame have yet to make this argument.

Indeed, one might think shame's proponents are making precisely the opposite argument: Prison is not the "appropriate" sanction for many offenders. Shame is. But if shame is the "appropriate" sanction for an offender-because prison is too harsh, and probation is too lenient-then offenders who "choose" shame over incarceration have indeed been coerced by the threat of imprisonment, even if judges are legally authorized to make that threat. ${ }^{150}$

\section{THE EDUCATING MODEL}

The shaming model begins with the expressive dimension of punishment and emphasizes shame's greater power to condemn an offender's wrongdoing compared with other alternative sanctions. Shame is then justified on the familiar grounds of retribution, deterrence, and rehabilitation. The alternative to shame is the educating model, which in many ways represents a more appealing approach to the problem of punishment.

shame over imprisonment when given the choice.").

${ }^{148}$ But not all. See, for example, Meg Jones, Woman Chooses Jail Instead of Shaming, Milwaukee J Sent 1 (May 23, 1997) (A woman convicted of welfare fraud opted for fifteen days in jail over a sixteen hour stint wearing sign on courthouse steps.).

${ }^{149}$ See Alan Wertheimer, Coercion 206-11 (Princeton 1987) (discussing various baselines against which the existence of coercion can be gauged).

${ }^{160}$ Moreover, at least under existing law, consent faces a legal problem. The problem stems from the traditional "rehabilitative" aim of probation. Where shaming penalties are imposed as a condition of probation, they must under many statutory schemes be reasonably related to the offender's rehabilitation. See, for example, Cohen and Gobert, The Law of Probation and Parole $\S 5.01$ at 182 (cited in note 106) ("By statute or judicial decision, virtually every jurisdiction supports the proposition that rehabilitation is at least one of the goals which probation . . . conditions should serve."). Under existing law, therefore, shame's proponents often must accept the bitter with the sweet. If they wish to defend shame as a consented-to condition of probation, they must explain how shame can rehabilitate. For their part, the courts have been skeptical of shame's rehabilitative potential. See notes 107-26 and accompanying text. 


\section{A. Educating and Shaming Contrasted}

Like the shaming model, the educating model has two dimensions-expressive and justificatory-but it differs from the shaming model along both of these dimensions.

\section{The expressive dimension.}

Rather than simply expressing condemnation of the offender's wrongdoing, as in the shaming model, punishment in the educating model is seen as a mode of bilateral communication, not just unilateral expression. ${ }^{151}$ The shaming model likens punishment to a monologue in which the state expresses its disapproval and disavowal of the offender's wrongdoing. To stretch the language metaphor still further, we might say punishment in the shaming model is designed to "yell" at the offender, loud and clear.

The educating model, in contrast, likens punishment to a dialogue in which the state punishes the offender in order to "wake him up," to get him to recognize and understand why what he has done was wrong, and ideally, to repent. The aim is to get the offender to reform himself. The dialogue is still a punitive one, however, and not just a chat. But rather than simply "yelling" at the offender, as in the shaming model, punishment in the educating model is intended to speak to him so he will listen and learn from what is said and not just passively receive our censure.

\section{The justificatory dimension.}

The educating model relies on what has been called the moral education, or moral reform, theory of punishment to justify the hardships it imposes. ${ }^{152}$ This theory is distinct from retribu-

${ }^{151}$ See R.A. Duff, Penal Communications: Recent Work in the Philosophy of Punishment, in Michael Tonry, ed, 20 Crime and Justice: A Review of Research 1, 33 (1996) (distinguishing between expressing condemnation and communicating with offender). See also R.A. Duff, Trials and Punishments 236 (Cambridge 1986) (stating that the goal of punishment is not merely condemnation but also bringing the offender to recognize the wrongfulness of his conduct); R.A. Duff, Alternatives to Punishment-or Alternative Punishments?, in Wesley Cragg, ed, Retributivism and Its Critics 43, 51 (Steiner 1992) ("LL]aw itself should involve a communicative process between the state and the citizen, not merely a one-way exercise of 'managerial control' by rulers over the ruled."), citing Lon Fuller, The Morality of Law 207-13 (Yale 2d ed 1969); Antony Duff, Punishment, Expression and Penance, in Heike Jung, Heinz Mouller-Dietz, and Ulfrid Neumann, eds, Recht und Moral 235, 239 (Nomos Verlagsgesellschaft 1991).

${ }^{162}$ For the best recent statements of this theory, see Duff, Trials at 233-66; Duff, 20 Crime and Justice at 1; Jean Hampton, The Moral Education Theory of Punishment, 13 Phil \& Pub Aff 208 (1984); Herbert Morris, A Paternalistic Theory of Punishment, 18 Am 
tivism and utilitarianism on which the shaming model is based, as well as from rehabilitation-although it shares affinities with all of these traditional justifications. ${ }^{153}$

Like utilitarianism (but unlike retributivism), the moral reform theory has a forward-looking aim: The goal of punishment is, simply put, the offender's moral education or reform. ${ }^{154}$ However, because the punishment inflicted on the offender is intended to persuade him that his offense was wrong, the moral reform theory, unlike standard utilitarian approaches, requires that the offender be treated as a responsible, autonomous agentas a being capable of rational address - and not merely as an object to be manipulated through coercion and fear. Philosophically, utilitarianism treats offenders not much differently from how a trainer would treat a misbehaving dog. ${ }^{155}$ To the utilitarian way of thinking, punishment appeals to the sense of pain. Under the moral reform theory, punishment ideally makes its appeal to the offender's reason.

Moreover, unlike traditional rehabilitative theory, which also aims at the offender's transformation, the moral reform theory seeks to accomplish this transformation in a distinctive way. It seeks reform through punishment, not as an adjunct to punishment. The mechanism of moral reform is punishment itself, not, as in the traditional rehabilitative model, some therapeutic re-

Phil Q 263 (1981). See also Nozick, Philosophical Explanations at 370-74 (cited in note 33) (articulating a version of moral reform theory but describing it as "teleological retributivism"). Compare John Griffiths, Ideology in Criminal Procedure, or A Third "Model" of the Criminal Process, 79 Yale L J 359, 389-90 (1970) (developing "Family Model" of criminal process and identifying "educational impact" of that process as "central" to the model). For earlier statements, see A.C. Ewing, The Morality of Punishment 73-125 (Patterson Smith 1970); Walter Moberly, The Ethics of Punishment 121-50 (Faber \& Faber 1968).

${ }^{133}$ The moral reform theory is a "hybrid" theory of punishment inasmuch as it tries to combine the insights of utilitarianism and retributivism. See Duff, 20 Crime and Justice at 3 (cited in note 151) (arguing for theories that "give punishment an end beyond itself but that ... find in the nature of that end substantive constraints on the means by which it may be pursued"). See also A.C. Ewing, Punishment as Moral Agency: An Attempt to Reconcile the Retributive and the Utilitarian View, 36 Mind 292, 292 (1927) (suggesting that the moral reform theory sets the "terms for a treaty of peace" between utilitarianism and retributivism).

A hybrid theory of this sort should be distinguished from more familiar "mixed" theories of punishment, which either impose retributive side constraints on an otherwise utilitarian theory, see H.L.A. Hart, 60 Proceedings of the Aristotelian Society at 8-12 (cited in 35), or allow utilitarian considerations to fix an offender's punishment within parameters otherwise established by a retributive theory. See von Hirsch, Censure at 47 (cited in note 64). See generally Michael Moore, Placing Blame: A General Theory of the Criminal Law 92-94 (Clarendon 1997) (describing two forms of mixed theories of punishment).

${ }^{154}$ See Nozick, Philosophical Explanations at 371 (cited in note 33) (describing moral reform theorists as "teleological retributivists").

${ }^{135}$ See, for example, Hampton, 13 Phil \& Pub Aff at 211 (cited in note 152). 
gime to which the offender is subject while he is being punished (e.g., while he is imprisoned). In addition, the moral reform theory does not embrace reform at all costs. It respects the offender's autonomy insofar as the offender is free to reject or ignore punishment's educative message. It delivers its message and withdraws. It does not insist on continuing to punish until the offender has changed his ways, which was one of the main objections leveled against the old rehabilitative ideal. ${ }^{156}$ In short, it seeks education, not indoctrination. ${ }^{157}$

Finally, like retributivism (but unlike utilitarianism), the moral reform theory prides itself on treating the offender as a responsible moral agent. Consequently, punishment must be proportionate to the seriousness of the offense and must be such that it respects her status as a rational agent, which disproportionate or excessive punishments do not. Again, consistent with respect for the offender's autonomy, the offender is free to reject or ignore punishment's educative message. Punishment under the moral reform theory does not seek simple submission. ${ }^{158}$ The offender can choose to accept the lesson, or not.

In short, the educating model and the moral reform theory conceive of punishment as a way to teach the offender how and why his offense was wrong. Ideally, therefore, the theory contemplates the following sequence: The offender comes through punishment to recognize and understand the nature of his offense, to experience guilt for what he has done, and finally, to repent his wrongdoing and to seek to make amends.

\section{Guilt versus shame.}

The mention of guilt brings us to one final contrast. "Selfconscious" emotions, which include pride, shame, guilt, and embarrassment, figure in both the shaming model and the educating model, but the emotions on which they are based are different.

Insofar as the shaming model is actually built on the emotion of shame, ${ }^{159}$ it stands again in contrast to the educating model, which is premised, if anything, on guilt and not shame. ${ }^{160}$ Shame

${ }^{1 s s}$ See, for example, Francis A. Allen, The Decline of the Rehabilitative Ideal-Penal Policy and Social Purpose 44-46 (Yale 1981) (discussing tension between penal rehabilitationism and liberal principles of consent and voluntarism).

${ }^{157}$ See Duff, 20 Crime and Justice at $50 \mathrm{n} 32$ (cited in note 151).

${ }^{158}$ See id at $46-47$.

${ }^{150}$ In all fairness, proponents of the shaming model do not appear too terribly concerned with the precise adverse emotional response punishment elicits, whether it is shame, guilt, or what not, so long as it elicits some adverse reaction. See, for example, Massaro, 89 Mich L Rev at 1901 n 99 (cited in note 41).

${ }^{100}$ For efforts to sort out the differences between shame and guilt, and between shame 
involves the idea of an audience; it is "connected with the thought that eyes are upon one. ${ }^{161}$ Guilt involves no such connection. The aim of the educating model is to get the offender himself to understand why what he did was wrong, an understanding to which the morally appropriate emotional response is guilt. The aim is not, as in the shaming model, to shame him in the eyes of others.

Moreover, among the family of self-conscious emotions, guilt enjoys at least two advantages over shame. First, shame and guilt differ in scope. Shame is global. ${ }^{162} \mathrm{~A}$ single act of wrongdoing is taken to be representative of a person's entire identity. As a result, shame can be shattering to the self's identity. Guilt, unlike shame, focuses on the individual's particular act of wrongdoing as distinct from the person as a whole.

Second, and more importantly, shame and guilt differ in the responses they typically elicit. Shame prompts one to hide, to seek shelter from public view, or worse, to strike back at the source of the shame in an effort at self-preservation. ${ }^{163}$ The shamed self is thus either passive and helpless, ${ }^{164}$ or enraged. In contrast, guilt prompts the self to try to make amends for the wrongdoing. Because guilt preserves some distance between the self and its wrongful act, it enables the self to become active and engaged in an effort to repair the damage the offense has caused. ${ }^{165}$ Shame supplies no such motive to repair.

and guilt and other adverse self-conscious emotions, see, for example, William Ian Miller, Humiliation chs 3-4 (Cornell 1993); Taylor, Pride, Shame and Guilt (cited in note 25); Massaro, 3 Psych, Pub Pol, \& L at 668-73 (cited in note 30).

${ }^{181}$ Taylor, Pride, Shame and Guilt at 53 (cited in note 25). Of course, the "thought that eyes are upon one" does not exclude the possibility of experiencing shame when completely alone. See id at 57-59 ("The person feeling shame feels exposed: he thinks of himself as being seen through the eyes of another .... One may feel shame when quite alone.").

${ }^{162}$ See id at 89 (" $[F]$ eelings of guilt are localized in a way in which feelings of shame are not localized; they concern themselves with the wrong done, not with the kind of person one thinks one is.").

${ }^{16}$ See June Price Tangney, et al, Shamed Into Anger? The Relation of Shame and Guilt to Anger and Self-Reported Aggression, 62 J Personality \& Soc Psych 669, 669 (1992) (concluding that "shame-proneness was consistently correlated with anger arousal").

${ }^{164}$ See Taylor, Pride, Shame and Guilt at 68 (cited in note 25) ("Thinking of herself as being seen in a certain way has revealed her to herself as inferior to what she believed, assumed, or hoped to be. As what is ultimately revealed is her lower standing she naturally feels helpless and hopeless."); Janie Lindsay-Hartz, Contrasting Experiences of Shame and Guilt, $27 \mathrm{Am}$ Beh Sci 689, 698 (1984) (Shame produces an urge to "hide and get out of the social realm" as well as "the sense of being small and exposed.").

${ }^{165}$ See Taylor, Pride, Shame and Guilt at 90 (cited in note 25) ("If feelings of guilt concentrate on the deed or omission then the thought that some repayment is due is in place here as it is not in the case of shame."); Lindsay-Hartz, 27 Am Beh Sci at 699 (cited in note 164) ("In order to feel guilty, it is essential that we also take responsibiltiy for this violation."). See also Herbert Morris, The Decline of Guilt, 99 Ethics 62, 67 (1988) ("II]n feeling guilty, one ... feels obliged to confess, to make amends, to repair, and to restore."); Sheldon X. Zhang, Measuring Shaming in an Ethnic Context, 35 Brit J Criminol 248, 260 
Assuming shame and guilt do indeed differ in these ways, then the state, if it tries to elicit any emotion when it punishes, should try to elicit guilt and not shame. Of course, eliciting a particular emotional response from a particular offender is not an exact science. Nonetheless, if the state aims at any such response-and both the shaming and educating model presuppose that it will-then it should be guilt. ${ }^{166}$

\section{B. Educational Anxieties}

The moral reform theory has in one form or another been around for quite some time. According to some, its roots may extend back to Hegel, ${ }^{167}$ and possibly to Plato, ${ }^{168}$ who insisted that wrongdoing could only be the result of moral blindness or ignorance. ${ }^{169}$ Despite its impressive lineage, however, the moral reform theory has seldom been prominent in discussions of punishment's justification. ${ }^{170}$ Why not?

(1995) (suggesting that influential theory linking "reintegrative shaming" to low crime rates in certain cultures is really based on guilt, because guilt, as distinct from shame, "involves feelings of regret and remorse").

${ }^{165}$ See June Price Tangney, Recent Advances in the Empirical Study of Shame and Guilt, 38 Am Beh Sci 1132, 1142 (1995) (concluding that a "range of empirical studies ... underscore that ... shame may represent the darker side of moral affect, while guilt may not be that bad after all'). See also R.E. Lamb, Guilt, Shame, and Morality, 43 Phil \& Phenom Res 329, 342 (1983) (arguing that "the role of shame in morality is much more of a logically peripheral sort of role than is the role of guilt, [and] that morality may suffer no essential injury when the possibility of shame is removed, but the excision of guilt cuts off its head").

${ }^{107}$ See Hampton, 13 Phil \& Pub Aff at 208 (cited in note 152), citing G.W.F. Hegel, The Philosophy of Right 66-74 (first published 1821) (Oxford 1952) (T.M. Knox, trans). See also J. Ellis McTaggart, Hegel's Theory of Punishment, 6 Intl J Ethics 479, 483 (1896) (arguing that for Hegel punishment is inflicted so that the offender is "forced into recognizing as valid the law which he has rejected in sinning, and so repent of his sin-really repent, and not merely be frightened out of doing so").

${ }^{16 s}$ See Hampton, 13 Phil \& Pub Aff at 208 (cited in note 152), citing Plato, The Laws, bks 5, 9. Compare Mary Margaret Mackenzie, Plato on Punishment 204-06 (California 1981).

${ }^{100}$ See Mackenzie, Plato on Punishment at 178 ("Plato offers three different analyses of the criminal disposition: that it is ignorant; that it is psychic disorder; that it is disease.").

${ }^{170}$ Indeed, one of the theory's most important proponents went over to the retributivist camp. Compare Hampton, 13 Phil \& Pub Aff at 208 (cited in note 152) (endorsing moral education), with Hampton, Expressive Theory at 1-2 (cited in note 33) (endorsing retributivism). A prominent defender of retributivism, however, went in the other direction. Compare Morris, 52 Monist at 477-78 (cited in note 64) (endorsing retributivism), with Morris, $18 \mathrm{Am}$ Phil Q at 264 (cited in note 152) (endorsing moral education).

Hampton continued to recognize a connection between her earlier moral education view and her latter-day retributivism. As she put it:

[T] he expressive view of retribution is both a useful supplement to and foundation for the moral education view, because it offers an explanation of what it is that punishment is saying such that it could be taken to be a morally educative message. It is not that pain teaches something about wrongness, but rather that it is symbolic of defeat 
Basically, three anxieties account for the theory's secondclass citizenship. The first fixes on whether punishment is necessary for moral education. The second deals with whether punishment, no matter who or what imposes it, can ever really be an educational experience. The third focuses on the legitimacy of trying to educate the wrongdoer when the educating entity is the state.

\section{Why punishment?}

If the goal of the moral reform theory is ideally to enter into a dialogue with the offender, to persuade him of the wrongfulness of his conduct, and to get him voluntarily to repent his wrongdoing, then wouldn't it be better simply to try to reason with him? Or at most, to subject him to verbal denunciation or an ethics lecture? Moreover, shouldn't his trial and conviction be enough to convince him? ${ }^{171}$ Why go further and subject him to the hard treatment of punishment?

For some theorists, condemnation, censure, or blame can be adequately expressed through some sort of purely symbolic or formal declaration. If hard treatment is justified, it must be on nonexpressive grounds. Typically, those grounds are utilitarian. On this view, therefore, hard treatment may say nothing that could not be said in words or symbolic gestures alone, but it is nonetheless needed as a "supplementary prudential disincentive. ${ }^{\text {172 }}$

For other theorists, actions speak louder than words. Hard treatment, and that of the right sort, is needed to make sure the condemnation is taken seriously. ${ }^{173}$ The moral reform theory

that makes it a useful (but not the only) tool for moral education.

Hampton, Expressive Theory at 21 (cited in note 33).

${ }^{171}$ The trial may, of course, be part of the process of moral education. See Duff, Trials at 115 (cited in note 151) ("The aim of a criminal trial is not merely to reach an accurate judgement on the defendant's past conduct: it is to communicate and justify that judgment-to demonstrate its justice-to him and to others.").

${ }^{172}$ von Hirsch, Censure at 14 (cited in note 64) ("[W]ith the need for prevention eliminated, there would no longer be a need for so ambitious, intrusive, and burdensome an institution as the criminal sanction."). See also Uma Narayan, Appropriate Response and Preventive Benefits: Justifying Censure and Hard Treatment in Legal Punishment, 13 Oxford J Legal Stud 166, 166 (1993) (" $[\mathrm{A}]$ compelling justification for legal hard-treatment partly requires an appeal to crime prevention.").

${ }^{173}$ See John Kleinig, Punishment and Moral Seriousness, 25 Israel L Rev 401, 417 (1992) (" $[F]$ or the most part our sensitivities are too dull, our hypocrisy too common, for mere face-to-face blaming to make its point."); Primoratz, 64 Phil at 198-202 (cited in note 36) (explaining that criminals, lacking human sympathy, respond only to "the language of self-interest," and that punishment "translates" condemnation into this language). See also David E. Cooper, Hegel's Theory of Punishment, in Z.A. Pelczynski, ed, Hegel's Politi- 
takes a similar view. Hard treatment is necessary because punishment "serves as a penance which the criminal should ideally come to will for himself." the wrongdoer accepts or imposes on himself in order to show his victim and the wider community that he understands what he did was wrong. So conceived, hard treatment is necessary in order to express the offender's conviction that he seeks to reform himself, to restore the communal bonds that his action destroyed or threatened, and to regain his good standing in the community. ${ }^{175}$ Moreover, hard treatment can reinforce repentance by concentrating the mind and forcing the offender to attend to his wrongdoing. ${ }^{176}$ Formal denunciation, while important, is simply not enough.

\section{Can punishment educate?}

Hard treatment may be necessary to impress upon some offenders the wrongfulness of their conduct, but don't some, if not all, offenders already know that what they did was wrong? And aren't some offenders beyond education altogether? And how on earth can one think modern modes of punishment, like imprisonment, are capable of morally educating?

Imagine an offender who immediately after committing his crime rushes to the police, confesses, pleads guilty, apologizes to his victim, and throws himself on the mercy of the court. Such an offender hardly seems as if he needs moral tutoring. On the contrary, a repentant wrongdoer, far from needing an education, is an example to us all. Indeed, we may not think he deserves any punishment, but if we do, then the moral education theory cannot tell us why. ${ }^{177}$

Likewise, "amoral risk-taker[s], revolutionary zealot[s], [and] sociopathic personalities"178 are, generally speaking, too far gone

cal Philosophy: Problems and Perspectives 151, 166-67 (Cambridge 1971) (attributing this view to Hegel).

${ }^{174}$ Duff, Trials at 245 (cited in note 151). For a wonderful collection of essays on the idea of repentance, see Amitai Etzioni and David E. Carney, eds, Repentence: A Comparative Perspective (Roman \& Littlefield 1997).

${ }^{178}$ See Duff, Trials at 247 (cited in note 151) ("Penance, as self-imposed suffering which expresses and assists repentance, aims to reconcile the penitent wrong-doer with others and with himself.").

${ }^{178}$ See id at 246 ("A penance can assist and strengthen my repentant understanding of what I have done: it ... provides a focus and stimulus for my penitent attention.").

${ }^{17}$ See Russ Shafer-Landau, Can Punishment Morally Educate?, $10 \mathrm{~L}$ \& Phil 189, 190 (1991) (noting that the goal of moral education is to "yield[ ] a person who is an autonomous individual freely attached to the good").

${ }^{178}$ Hampton, Expressive Theory at 21 (cited in note 33), citing Joel Feinberg, Harmless Wrongdoing 304-05 (Oxford 1988). 
for punishment to have much of an educative effect. We might hope that punishment will turn them around, but such hope is often just wishful thinking. To recommend punishing such defiant offenders, the moral education theory would have to posit a very strong relationship between moral knowledge and wrongdoing, i.e., that anyone who commits a crime by definition does not understand that what he did was wrong, or else he would not have committed it. But that's implausible. Many if not most offenders realize what they did was wrong. Once again, if we think such offenders should nonetheless be punished, the moral education theory cannot tell us why.

The existence of already repentant and unremittingly defiant offenders does not, however, undermine the moral education theory. It only limits its scope. When an offender already has repented, or when the chances of getting him to repent are slim-tonone, then a theory of punishment whose goal is to set in motion a cycle of recognition-guilt-repentance simply "has no place."179 This does not mean the offender shouldn't be punished. It only means that his punishment must be based on grounds other than moral education-most likely deterrence for the defiant, and retribution for the repentant. ${ }^{180}$ Moral education should be part of the picture, but it can't be all of it. ${ }^{181}$

Consequently, the moral reform theory may only apply to a relatively narrow range of offenders. ${ }^{182}$ It all depends on how many offenders fall within the "already repentant" and "defiant" categories. Those categories may cover many or most criminal offenders, but a number of offenders may lie between those two extremes. These offenders may know in an abstract sense that they have done wrong (first-order moral knowledge) but fail to fully appreciate the nature of that wrong (second-order moral knowledge). ${ }^{183}$ Their cognitive apprehension of their wrongdoing may be

${ }^{179}$ James Griffin, Well-Being: Its Meaning, Measurement and Moral Importance 272 (Oxford 1986).

${ }^{180}$ But see Duff, 20 Crime and Justice at 54 (cited in note 151) (arguing that punishment of the already repentant is justified because "some penance is needed to reinforce that repentance"; likewise, punishment of those we are "certain" will remain unrepentant is justified because "we owe it to them not to regard them as beyond moral salvation").

${ }^{181}$ See Morris, $18 \mathrm{Am}$ Phil Q at 271 (cited in note 152) ("The practice of punishment is complex and any justification proposed as an exclusive one must, in my judgment, be met with skepticism, if not scorn.").

${ }^{162}$ See von Hirsch, Censure at 75 (cited in note 64) ("Cases where punishment functions ... as a penitence leading to actual penance ... may be the exception rather than the rule.").

${ }^{163}$ See Lisa Anne Smith, The Moral Reform Theory of Punishment, 37 Ariz L Rev 197, 203 (1995). The moral reform theory thus might apply only to offenders who suffer from a form of "moral ignorance," but who nonetheless appreciate the wrongfulness of their con- 
fine, but their affective or emotional apprehension of it may be lacking. ${ }^{184}$ Punishment under the moral reform theory tries to tutor this affective capacity, teaching the second-order lesson many offenders may need.

Still, moral reform may sound good in theory, but isn't it silly to think that our contemporary modes of punishment can educate? Can one honestly think our dominant mode of punishment-imprisonment-is capable of providing moral education? When the penitentiary was first created, hopes ran high that it really would be a place for the transformation of men's souls, ${ }^{185}$ but history has dashed these hopes. No one would seriously claim that today's prisons are sites of moral reform. ${ }^{186}$ If anything, the opposite seems more likely.

Nor do our other dominant modes of sanctioning appear especially likely to educate an offender in the way moral reform theory envisions. Probation sets limits on what an offender can do. It may require him to stay away from bad influences and try to keep a job, but it doesn't try to show him why what he did was wrong. Likewise, community service may introduce the offender to the virtues of helping others, but it too does nothing to show the offender why what he did was wrong. And fines simply transfer wealth from the offender to the state. What's the moral lesson there? Perhaps nothing, or worse, perhaps it is that the well-to-do can buy their way out of the wrongdoing that the not-so-well-todo must pay for with prison. ${ }^{187}$

Yet the gap between the moral reform theory and our actual practices points less to any weakness of the theory and more to the need for innovation in the kinds of punishment the state imposes. As discussed below, some of the punishments commonly-

duct.

${ }^{284}$ I am indebted to Dan Kahan for this point.

${ }^{105}$ See Hirsch, Rise of the Penitentiary at 18-20 (cited in note 5) (describing this "philanthropic paradigm of carceral rehabilitation"); Rothman, Discovery of the Asylum at 107 (cited in note 5) ("The prison would train the most notable victims of social disorder to discipline, teaching them to resist corruption.").

${ }^{18}$ See, for example, Shafer-Landau, $10 \mathrm{~L} \&$ Phil at 203-04 (cited in note 177) (concluding that "we have as yet no good reason for supposing incarceration an efficacious means of morally educating the criminal offender").

${ }^{187}$ But see Duff, Alternatives at 55-61 (cited in note 151) (arguing that traditional forms of punishment, including community service, probation, and imprisonment, can be understood as morally educative). Duff has since retreated from the position that prison can be morally educative. See Jeffrie G. Murphy, Repentence, Punishment, and Mercy, in Etzioni and Carney, eds, Repentance 143, 167 (cited in note 174) (quoting Duff in 1995 personal correspondence as saying, "I'm inclined now to place less weight on imprisonment as a mode of communicative punishment (though it can have some place in such an account), and more weight on [n]on-custodial punishments"). 
though mistakenly-seen as shaming penalties offer innovation along these lines.

\section{Should punishment educate?}

If with the right offenders and the right punishments, hard treatment can educate, the question remains: Should punishment even try to educate, especially since it is the state that's doing the punishing/educating?

Punishing offenders in order to prevent future crime, or simply because they deserve it, is one thing. Punishing offenders in order to get them to repent, however, sounds like it might be a suitable occupation for a cleric vis-à-vis a member of his congregation, but not for a liberal state vis-à-vis one of its citizens. ${ }^{188}$ Isn't the moral reform theory illiberal? ${ }^{389}$

Neutrality is often said to be the defining characteristic of the liberal state..$^{190}$ Put more grandly, the state must remain neutral with respect to, and must not try to coerce its citizens into embracing, any particular vision of the "good life." Legal perfectionists may think the state should shepherd its citizens to virtue, but liberals don't. On the contrary, the liberal state should limit itself to supplying a framework of basic rights within which

${ }^{168}$ Utilitarianism may seem perfectly compatible with liberalism. See Jeffrie G. Murphy, Retributivism, Moral Education, and the Liberal State, in Jeffrie G. Murphy, Retribution Reconsidered: More Essays in the Philosophy of Law 15, 20 (Kluwer 1992) (suggesting that liberalism entails utilitarianism). The compatibility of retribution and liberalism, however, is less clear. Compare id at 24-25 (suggesting that retributivism and liberalism may be incompatible); Jeffrie G. Murphy, Legal Moralism and Liberalism, 37 Ariz L Rev 73, 83 (1995) (same); Stanley C. Brubaker, Can Liberals Punish?, 82 Am Pol Sci Rev 821, 825 (1988) (same), with Jean Hampton, Liberalism, Retribution and Criminality, in Jules L. Coleman and Allen Buchanan, eds, In Harm's Way: Essays in Honor of Joel Feinberg 159,176 (Cambridge 1994) (arguing that retributivism and liberalism can be compatible). Compare also Wojciech Sadurski, Theory of Punishment, Social Justice, and Liberal Neutrality, 7 L \& Phil 351, 373 (1989) (arguing that liberalism entails retributivism), with Michael Davis, The Relative Independence of Punishment Theory, 7 L \& Phil 321, 328-30 (1988) (suggesting that punishment theory is "relatively independent" of political theory).

${ }^{109}$ The same charge might be made against the shaming model. Compare Jeffrey Rosen, The Social Police, The New Yorker 170, 175 (Oct 20 \& 27, 1997) ('Kahan's enthusiasm for shaming penalties suggests a connection between the Chicago school of social norms and an older, more conservative, and arguably creepier tradition of legal thought, embodied by Lord Devlin, a British legal theorist."). It's another matter altogether whether that charge is fair.

${ }^{100}$ See, for example, Ronald Dworkin, Liberalism, in Ronald Dworkin, A Matter of Principle 181, 191-92 (Harvard 1985) (arguing that liberalism requires "government [to] be neutral on what might be called the question of the good life"). I realize that this claim about liberalism is controversial insofar as liberalism may not really be neutral, nor really committed to neutrality. See, for example, Steven Shiffrin, Liberalism, Radicalism, and Legal Scholarship, 30 UCLA L Rev 1103, 1134 (1983) (arguing that "ethical liberalism is not entirely neutral" and developing a non-neutral conception of liberalism). 
each individual can discover for himself or herself what the good life means. If so, then isn't the state stepping beyond its legitimate sphere of influence when it takes it upon itself to "morally educate" its criminal offenders?

The moral reformist has two replies to this concern. One stays within the limits of liberalism. The other goes beyond them.

First, within a liberal state, the so-called "harm principle" specifies the legitimate boundaries of the criminal law. ${ }^{191}$ The state can validly criminalize only those actions that result in one citizen's harming of another. But so long as it stays within those boundaries, the state does no wrong if it tries to get criminal offenders to understand and accept the constraints that the criminal law justifiably imposes. Although considerable debate surrounds the scope of the harm principle, ${ }^{192}$ the state does not act illiberally if it tries to educate its citizens to respect the prohibitions of the criminal law, so long as the criminal law itself respects the limits imposed by the harm principle. The moral reform theory and liberalism can thus peacefully coexist, all within the limits of liberalism.

Still, this response may seem incomplete or unsatisfying. ${ }^{193}$ After all, the moral reform theory does ask the state to busy itself trying to improve the moral character of its citizens, even if the lessons it tries to teach are consistent with the liberal harm principle. Moreover, because the goal of the moral education theory is the offender's voluntary repentance and reconciliation with the community, it presupposes that all citizens guilty of criminal wrongdoing should value this moral reintegration into the community. If so, doesn't that presuppose a vision of the good life in

${ }^{191}$ For the classic statement of this view, see John Stuart Mill, On Liberty 13 (first published 1859) (ITT Bobbs-Merrill 1956) (Currin V. Shields, ed) ("[T] which power can be rightfully exercised over any member of a civilised community, against his will, is to prevent harm to others."). For more recent statements, see Joel Feinberg, Harm to Others 15 (Oxford 1984) (providing "an effort to vindicate the traditional liberalism derived from Mill's On Liberty ... qualified and reformulated in the light of the many accumulated difficulties and criticisms"); H.L.A. Hart, Law, Liberty and Morality 5 (Stanford 1963) (defending Mill's harm principle with respect to the use of legal coercion to enforce morality).

${ }^{122}$ See, for example, Feinberg, Harm to Others (discussing scope and content of harm principle); Andrew von Hirsch, Extending the Harm Principle: Remote' Harms and Fair Imputation, in A.P. Simester and A.T.H. Smith, eds, Harm and Culpability 259, 276 (Oxford 1996) (explaining "why it is important to develop fair-imputation principles when dealing with remote risks" as a ground for criminalization of conduct).

${ }^{109}$ See, for example, von Hirsch, Censure at 73 (cited in note 64) (arguing that the moral reform theory may be consistent with the harm principle but that it remains objectionable insofar as it continues to focus on the "quality of the actor's own moral responses to his harmful act"). 
which such communal attachments are privileged or highly prized? ${ }^{194}$

To meet this concern, one must travel outside liberalism proper and move toward a more communitarian conception of the state, in which it is the state's business to be concerned with the moral development of its citizens. If this sounds like a vision of how punishment functions in more intimate settings like that of the family, it should. ${ }^{195}$ The moral reform theory draws much of its inspiration from the operation of punishment in such intimate settings, trying to imitate that model for the state's own practices of punishment wherever possible.

Which again raises the objection: A liberal state should not concern itself with the moral development of its citizens. When the state punishes, it should stay away from the "inner citadels of the soul"; its aims should not include "bring[ing] about certain responsive attitudes in those whom it condemns." ${ }^{\text {196 }}$ Repentance is within the jurisdiction of the church, where it rightly belongs. Or, as the owner of one Georgia company forced to advertise its conviction for immigration violations in a Spanish-language newspaper put it, taking responsibility is one thing, but "laying your sins at the foot of the cross, isn't that a little much?"197

Critics of the communitarian state are right to be worried. The moral education theory of punishment asks a great deal. Of those who impose punishment, it asks that they do so in the spirit of a parent punishing a child. Of those who receive punishment, it asks that they respond to it and accept it as a way of making amends. All of which may be asking too much of citizens of the modern state. ${ }^{198}$ Moreover, the moral education theory always runs the risk of state overreaching. The state might not rest until the "heretic" has been "converted." Prudence, if not princi-

${ }^{194}$ See John Deigh, On the Right to Be Punished: Some Doubts, 94 Ethics 191, 203 (1984) (stating that moral "reform theory is built on the postulation of two basic, human goods: the good of harmonious social relations and the good of well-integrated moral personality").

${ }^{205}$ See Griffiths, 79 Yale I J at 387 (cited in note 152) (stating that "concern for what, broadly speaking, is 'good for' a defendant caught up in the criminal process" is central to the "Family Model" of that process). But see Sheri Lynn Johnson, Confessions, Criminals and Community, 26 Harv CR-CL L Rev 327, 384 (1991) ("The present correctional system is not imbued with love and concern, nor is there any apparent prospect for realizing such a system.").

${ }^{196}$ von Hirsch, Censure at 74 (cited in note 192).

${ }^{107}$ Woolner, Am Law at 34 (cited in note 9).

${ }^{108}$ See Ellis McTaggart, Studies in Hegelian Cosmology 147 (Cambridge 1901) ("The modern citizen ... does not regard [the state] as something above and superior to himself, as the ancient citizen regarded his city, as the child regards his parent, or as the religious man his God."). 
ple, might thus counsel the state to punish with more modest goals in mind. ${ }^{199}$

A complete reply to this objection would lead deep into political philosophy and probably require a full-blown defense of the communitarian state. For the time being; I settle for a more contextual inquiry. Some punishments that might find support in the moral education theory, such as requiring offenders to attend church, ${ }^{200}$ clearly do offend liberal sensibilities. But are those sensibilities likewise offended when, say, a slumlord is required to spend some time in his slum? I think the answer is far less clear.

\section{Lex Talionis}

Even if punishment can educate, and even if the state should try to educate through punishment, how exactly can punishment educate? The answer according to the moral reform theory is the principle of lex talionis, popularly known as an "eye-for-an-eye." But isn't an appeal to that discredited principle enough to discredit the theory? ${ }^{201}$ No. The following Part explains why not. ${ }^{202}$

\section{How to punish? Traditional theories.}

Philosophical discussions of punishment usually focus on why we punish, and on how much we punish. The traditional theories of punishment-retribution and deterrence-usually say very little, however, about how we punish, ${ }^{203}$ which is not to say that they say nothing about it.

Utilitarianism, for example, encourages architects of punishment to get the most deterrence at the lowest possible cost. Consequently, modern-day economic scholars building on the insights of classical utilitarianism have recommended greater use of fines, ${ }^{204}$ which can in theory have the same deterrent effect as

${ }^{100}$ See id at 145 ("[I]f the state allows its attention to be distracted in the humble task of frightening criminals from crime, by the higher ambition of converting them to virtue, it is likely to fail in both.").

${ }^{200}$ See, for example, Cook, Liberty at 11 (cited in note 11).

${ }^{201}$ See Shafer-Landau, $10 \mathrm{~L} \&$ Phil at 201 (cited in note 177) (noting that lex talionis represents the best way to achieve "empathic knowledge" but concluding that the application of lex talionis "would often involve clear violations of autonomy").

${ }^{202}$ The following Part draws heavily on the important, though unfortunately muchneglected, article by Jeremy Waldron, Lex Talionis, 34 Ariz L Rev 25 (1992).

${ }^{203}$ See Duff, Alternatives at 43 (cited in note 151) (noting that philosophical discussions of criminal punishment rarely focus on "what material forms ... punishment [can] properly take").

${ }^{20}$ See, for example, Richard Posner, The Economic Analysis of Law 227 (Little, Brown 4th ed 1992) ("From an economic standpoint, the use of fines should be encouraged."); Gary S. Becker, Crime and Punishment: An Economic Approach, $76 \mathrm{~J}$ Pol Econ 169, 19398 (1968) (presenting "several arguments which imply that social welfare is increased if 
imprisonment but are actually profitable to the state. They also note that cutting back on the resources invested in detecting and prosecuting crime, but then imposing heavy fines on those who do face judgment, can also, again in theory, make punishment cheaper with no sacrifice in the overall level of general deterrence. ${ }^{205}$

Retributivism has even less to say about how to punish than does utilitarianism. Setting aside for the moment the venerable principle of lex talionis, retributivism generally has been preoccupied with grading punishments (the "how much" question) and less with constructing punishment (the "how to" question). ${ }^{206}$ To its credit, retributivism insists that the severity of punishment must be proportional to the moral seriousness of the offense. Bentham described this demand for proportionality as a "good one," but also as one that was "more oracular than instructive." ${ }^{~ 207}$ Contemporary theorists have tried to give greater content to the idea, ${ }^{208}$ though the Supreme Court has all but given up trying to decide when a punishment becomes disproportionate and therefore offensive to the Eighth Amendment, leaving the matter largely to legislative judgment. ${ }^{209}$

Compared with utilitarianism and retributivism, the moral reform theory of punishment has quite a bit to say about how to punish. Surprisingly though, what it says is in praise of lex talionis. This obviously requires some elaboration and explanation.

2. The talionic principle: objections.

In its simplest (and crudest) formulation, lex talionis requires that the punishment an offender suffers mirrors the harm he inflicted on his victim.

fines are used whenever feasible").

${ }^{205}$ See Becker, 76 J Pol Econ at 184; David Friedman, Why Not Hang Them All, or The Virtues of Inefficient Punishment 2 (Nov 27, 1995) (unpublished manuscript on file with U Chi L Rev).

${ }^{200}$ See, for example, Paul H. Robinson, Desert, Crime Control, Disparity, and Units of Punishment, in Anthony Duff, et al, eds, Penal Theory and Practice: Tradition and Innovation in Criminal Justice 94 (Manchester 1994) ("[N]otions of desert concern primarily the amount of punishment.").

${ }^{207}$ Jeremy Bentham, Principles of Penal Law, in John Bowring, ed, 1 The Collected Work of Jeremy Bentham 365, 399 (William Tait 1843).

${ }^{208}$ See, for example, von Hirsch, Censure at 29-35 (cited in note 64) (arguing that a "living standard" measurement should be used to determine proportionality of punishment to crime").

${ }^{20}$ See, for example, Harmelin v Michigan, 501 US 957, 965 (1991) (opinion by Scalia) ("[T]he Eighth Amendment contains no proportionality guarantee."). See also id at 1001 (Kennedy concurring) (concluding that the Eighth Amendment "forbids only extreme sentences that are 'grossly disproportionate' to the crime"). 
Today, lex talionis is the object of philosophical derision and is usually found only in discussions about the death penalty. ${ }^{210}$ When the principle is cast in its crude form, this derision is well deserved. Lex talionis is widely thought, for example, to recommend morally unacceptable modes of punishment (like gouging out eyes) for some offenses (like assault), while having little or nothing to say about how to punish other offenses (like perjury or blackmail).

In particular, lex talionis faces three main objections to which an acceptable interpretation of the principle must reply:

Taken literally, lex talionis would authorize barbarous treatment. Rapists would be raped, mutilators mutilated, and so on. Lex talionis is therefore morally grotesque. ${ }^{211}$

Taken literally, lex talionis cannot successfully prescribe a punishment for offenses, like perjury, in which the loss is not assignable to any particular victim. Lex talionis may apply when we know who got hurt and how they got hurt, but many crimes lack a specific victim. Lex talionis is therefore woefully incomplete. ${ }^{212}$

Taken literally, lex talionis focuses only on the harm the offender has caused and ignores the offender's moral culpability. An offender guilty of intentional homicide would get the same punishment as one guilty of reckless homicide because the resulting harm-the victim's death-is the same. Lex talionis is therefore an ugly recipe for disproportionate punishments. ${ }^{213}$

A principle that defends morally grotesque punishments, that is incomplete, or that recommends disproportionate punishments is unlikely to carry much appeal. Still, talionic or talioniclike punishments have an enduring-if sometimes strange and disturbing-allure.

Part of that allure involves the sense that talionic punishments (also known as mirroring or analogical punishments) "fit"

${ }^{210}$ See, for example, Ten, Crime at 151 (cited in note 67) (" $[$ C]apital punishment seems to be the only form of punishment which is still frequently supported by appeal to lex talionis.").

${ }^{211}$ See, for example, id at 152 (arguing that lex talionis would underwrite "certain forms of punishment which are too cruel to be tolerated by any civilized penal system").

${ }^{212}$ See, for example, Nicola Lacey, State Punishment: Political Principles and Community Values 17 (Routledge 1988) (arguing that lex talionis supplies clear guidance as to the proper measure of punishment in only a limited number of cases); Ten, Crime at 151 (cited in note 67) (noting that lex talionis "cannot be applied to many crimes").

${ }^{213}$ See, for example, Lacey, State Punishment at 17 (cited in note 212) (arguing that lex talionis does not include the principle of responsibility as a limit on who may be punished); Ten, Crime at 152 (cited in note 67) (noting that lex talionis is objectionable because the "formula it uses for determining the correct punishment is solely in terms of the harm done by the crime, and makes no allowance for the morally important mental states of the offender"). 
the crime in a way that seems intuitively "natural" or "right."14 Examples of talionic punishments abound, though more in history and literature, and less so in contemporary practice. ${ }^{215}$ In the ancient Greek world, for instance, the tongue of an offending orator might be removed, sex offenders might be castrated, soldiers who wantonly burned houses might be allocated poor accommodations, and a false accuser might receive the punishment that would have been received by the person he falsely accused. ${ }^{216}$ Greek mythology is another rich source of talionic punishments, including the penalty of the "golden touch" visited upon Midas for his avarice. ${ }^{217}$ The rings of Dante's Hell provide still more examples of talion-inspired justice. ${ }^{218}$

Yet whatever intuitive appeal it may have, lex talionis remains at face value a morally unacceptable principle by which to inflict punishment. How, then, can the moral reform theory possibly embrace it?

\section{Rehabilitating lex talionis.}

The philosophical rehabilitation of lex talionis begins with the obvious: It cannot be interpreted literally. If lex talionis requires the state to impose on an offender as punishment the "same" harm he inflicted on his victim (assuming there is one), then lex talionis is an impossible maxim to follow because the punishment will, of necessity, "take place at a different time and with different dramatis personae from those of the original offense. ${ }^{219}$ Thus, wholly apart from any moral objections to the literal reading of lex talionis, such a reading is itself literally impos-

${ }^{24}$ See W.S. Gilbert, The Mikado, or The Town of Titipu: The Complete Text of the Gilbert \& Sullivan Opera 32 (Winthrop Armes Gilbert \& Sullivan Opera Co 1939) ("My object all sublime, I shall achieve in time, to make the punishment fit the crime.").

${ }^{215}$ But see Sam S. Souryal, Dennis W. Potts, and Abdullah I. Alobied, The Penalty of Hand Amputation for Theft in Islamic Justice, $22 \mathrm{~J}$ Crim Just 249, 255 (1994) (describing punishment of hand amputation for theft in context of Islamic law).

${ }^{216}$ See Trevor J. Saunders, Plato's Penal Code: Tradition, Controversy and Reform in Greek Penology 358-59 (Oxford 1991) (listing a compilation of crime-specific punishments culled from ancient Greek writers and other ancient Greek historical sources). See also George Ives, A History of Penal Methods 54-57 (Patterson Smith 1970) (describing "poetic" punishments used in the Middle Ages).

${ }^{217}$ See Saunders, Plato's Penal Code at 360.

${ }^{218}$ For example, Dante's hypocrites walk slowly around the eighth ring of Hell wearing cloaks that are "dazzlingly gilded" on the outside but "all of lead" on the inside, thus reflecting the outward lightness but inward burden of their hypocrisy. Dante Alighieri, 1 The Divine Comedy of Dante Alighieri: The Inferno 349 (Oxford 1996) (Robert M. Durling, trans and ed).

${ }^{219}$ Waldron, 34 Ariz L Rev at 32 (cited in note 202). See also St. George Tucker, ed, 5 Blackstone's Commentaries *12-14 (Lawbook Exchange 1996) (discussing impossibility of applying lex talionis literally). 
sible to follow. ${ }^{220}$ Moreover, once we accept a nonliteral interpretation of the basic talionic idea of somehow reflecting the offense back on the offender through punishment, the repertoire of possible "talionic," or analogical, punishments extends well beyond those cruel inflictions that usually come to mind.

Every criminal act has certain features. Some of these features make the act wrong, while others are morally irrelevant and have little if anything to do with why the action was wrong. For example, if an offender throws a brick one Friday evening that causes the victim to lose sight in one eye, what makes the act wrong is that it violated the victim's bodily integrity. It may or may not be relevant that the victim's physical injury was the loss of sight in one eye, but the fact that a brick caused the injury or that the crime occurred on a Friday evening is irrelevant; neither fact affects our assessment of the act's wrongfulness.

The key to intelligent application of the talionic principle is therefore identifying which features of the offender's act are morally relevant, and then devising morally acceptable inflictions that somehow reflect the relevant features back onto the offender. Which features of any particular criminal act one should try to reflect in an offender's punishment and which to ignore depends on the background theory of punishment deployed in support of lex talionis. In the end, the effort to identify the relevant elements will be "guided by our best sense of what made the action wrong in the first place. $\$ 221$

Although lex talionis usually is associated with retributivism, especially the retributivism of Kant, ${ }^{222}$ that association is not inevitable. Indeed, the father of utilitarianism, Jeremy Bentham, was also something of a supporter of lex talionis, though his support was of course based on his utilitarianism. According to Bentham, for example:

Punishment can act as a preventative only when the idea of it, and of its connexion with the crime, is present to the mind. Now, to be present, it must be remembered, it must have been learnt. But of all punishments that can be imag-

${ }^{200}$ See Waldron, 34 Ariz L Rev at 32 (cited in note 202).

${ }^{21}$ Id at 37 . Waldron goes on: lex talionis "involves nothing more ... than (a) thinking through why the offense is wrong, and (b) thinking about the possibility of . . reversal of roles, which would allow the offender to experience an action relevantly like his offense from another point of view." Id at 45.

${ }^{222}$ See Immanuel Kant, The Metaphysical Elements of Justice *332 (Bobbs-Merrill 1965) (John Ladd, trans) ("Only the Law of retribution (jus talionis) can determine exactly the kind and degree of punishment."). See also Kleinig, Punishment and Desert at 121 (cited in note 67) ("Of those who have appealed to the lex talionis, Kant comes closest to a literal form."). 
ined, there are none of which the connexion with the offence is either so easily learnt, or so efficaciously remembered, as those of which the idea is already in part associated with some part of the offense. ${ }^{223}$

Lex talionis was "admirable" in this respect. ${ }^{224}$ Although Bentham believed literal lex talionis was "rarely practicable," ${ }^{225}$ he devoted an entire chapter to a discussion of punishments that were "analogous" to the offense. ${ }^{226}$

Lex talionis (suitably refined) also fits the needs of the moral reform theory. ${ }^{227}$ The moral education theory posits that the criminal offender, at some second-order level, does not fully understand or appreciate what he has done wrong. The aim of punishment is thus to show him, if possible, what that wrong was, and "[h] uman nature [may be] such that the vivid lesson conveyed by 'turning the tables' on the offender is the quickest route to awareness of wrong-doing and repentance. ${ }^{7228}$ In other words, lex talionis, read against the background of the moral education theory, urges that sanctions be designed in a way that makes an offender directly or vicariously experience the harm he has caused. Read in this way, lex talionis is a mode of instruction based on the simple idea of role reversal.

Indeed, the idea of role reversal nicely captures both the talionic and the educative elements involved in many creative punishments. For instance, in the brick-throwing example the court ordered the offender, a juvenile, to pay $\$ 24,000$ in restitution; but it also ordered him to wear a patch over his eye that he could remove only when sleeping. ${ }^{229}$ The hope, one imagines, was that he might really learn what it was like to suffer in the way he made his victim suffer or, in other words, to teach him a little empathy. ${ }^{230}$ Recast in this way, lex talionis is much less vulnerable to the three objections mentioned above.

${ }^{23}$ Bentham, Principles of Penal Law at 403 (cited in note 207).

${ }^{2 x}$ Id.

${ }^{225} \mathrm{Id}$.

${ }^{223}$ See id at ch VIII ("Of Analogy Between Crimes and Punishments").

${ }^{27}$ See Hampton, 13 Phil \& Pub Aff at 227 (cited in note 152) (stating that "the intuition behind lex talionis ... . best supports the concept of punishment as moral education").

${ }^{223}$ Waldron, 34 Ariz L Rev at 31 (cited in note 202). See also Moberly, Ethics of Punishment at 207 (cited in note 152) ("In punishing ... you seek to destroy [the offender's] will to evil by holding up a mirror before his eyes, in order that he may see himself as he really is."); R.S. Peters, Ethics and Education 279 (Allen 1966) ("The effectiveness of ... punishments in moral education depends largely on the extent to which they bring home imaginatively the consequences of actions as they affect other people.").

${ }^{20}$ See Salamone, Eye Patch, Orlando Sent at A1 (cited in note 17).

${ }^{20}$ See Lynne N. Henderson, Legality and Empathy, 85 Mich L Rev 1574, 1579 (1987) (Empathy is "understanding the experience or situation of another, both affectively and 
First, lex talionis isn't morally grotesque, since it needn't embrace barbarous or cruel punishments. Rape, for example, may be described at various levels of abstraction. If rape is the sexual violation of a woman by a man, then it would be impossible to apply lex talionis in the case of rape, because the gender-specificity of the offense makes raping a rapist impossible. If we ascend to a slightly higher level of abstraction and treat rape as a crime of sexual violation regardless of gender, we may avoid the problem of gender-specificity, but we still encounter the problem of barbarity, because sexually violating a rapist would be morally outof-bounds.

If we take still one step more, however, we can see how it might be possible to add a talionic element to existing sanctions against rape. Part of the harm of rape consists in the "trauma, indignity and degradation" it entails. ${ }^{231}$ Short of actually physically violating an offender in order that he might himself experience that trauma, perhaps the closest one can come to a talionic treatment of rape would be to force the offender to experience it vicariously. Jean Hampton, for example, has described an "innovative program" in which imprisoned sex offenders are "forced to listen to the words and accusations of rape victims, and they engage in role playing in which they assume the role of the women they raped." ${ }^{\text {"232 }}$ According to Hampton, "[s]uch experiences force [the men] to deal with the feelings of anger, hurt, and frustration that they come to realize their actions have caused others. ${ }^{.2233}$

Second, the potential scope of lex talionis is greater than it might at first appear. Applied with enough flexibility and imagination, it might even be able to handle offenses that lack an identifiable victim and are generally understood instead to be offenses against the public or against the integrity of some vital public in-

cognitively, often achieved by imagining oneself to be in the position of the other.").

${ }^{231}$ Waldron, 34 Ariz L Rev at 37 (cited in note 202).

${ }^{222}$ See Jean Hampton, Correcting Harms Versus Righting Wrongs: The Goal of Retribution, 39 UCLA L Rev 1659, 1689-90 (1992), citing Claire Glasman, Discussing Rape With Rapists-Or Can Men Change?, 13 New L J 969 (July 14, 1989). See also Tom Mashberg, About Face: Program Forces Batterers to Accept Responsibility For Their Actions, Chi Trib 1 (Oct 3,1994 ) (describing similar confrontational program used as condition of probation for men convicted of spousal abuse). Confrontational encounters of this kind are different from criminal mediation programs that "stress[ ] forgiveness and reconciliation before victims have the vindication of a public finding that the offender is guilty." Jennifer Gerarda Brown, The Use of Mediation to Resolve Criminal Cases: A Procedural Critique, 43 Emory L J 1247, 1249 (1994). See also Harry Mika, The Practice and Prospect of Victim-Offender Programs, 46 SMU L Rev 2191, 2196 (1993) (noting that the Victim-Offender Reconciliation Program is a process of negotiation that seeks to facilitate restitution [to the victim]").

${ }^{23}$ Hampton, 39 UCLA L Rev at 1690. 
stitution. Consider, for example, perjury. We might say that the "victim" of perjury is the person who suffers as a result of the offender's lie under oath. But that would miss a good deal of what makes perjury wrong, because perjury not only injures the target of the lie, it also jeopardizes the integrity of the court and its factfinding procedures. How might one bring home to an offender the relatively more abstract nature of this wrong? How best to educate him?

Jeremy Waldron offers the following thoughts. Insofar as the wrongness of perjury involves impeding the ability of the courts to function as they should, one might deny the perjurer access to the courts for some specified period of time, with a view that the offender might learn the value of preserving the courts' integrity. ${ }^{234}$ Or consider the crime of blackmail. If the wrong in blackmail is the offender's invasion of the victim's privacy, ${ }^{235}$ lex talionis might suggest that a court officer be authorized to rummage through the offender's belongings and publish some aspect of the offender's life he wishes to keep concealed from public view. ${ }^{236}$

Lastly, lex talionis need not justify disproportionate punishments. Lex talionis is often dismissed because, as traditionally construed, it looks only to the harm the offender caused and remains indifferent to his mental state. Under this traditional view, an intentional homicide would get the same punishment as a negligent or reckless one. Surely that can't be right. Once it's recast, however, lex talionis might be able to account for an offender's mental state. Recognizing that an intentional homicide is different from an indifferent one, we might try to register that difference in the lesson our punishment aims to teach the offender. Again, Waldron offers an illustration. For example, inasmuch as the wrongfulness of negligent or reckless conduct consists in part in subjecting another person to substantial and unjustifiable risk or chance of harm, perhaps the punishment or the degree of punishment to which the offender is subject could itself be made subject to chance. ${ }^{237}$

${ }^{24}$ See Waldron, 34 Ariz L Rev at 44 (cited in note 202) ("Such a punishment is unfamiliar, but [lex talionis] makes no claim to model our 'intuitions' of just punishment, if those 'intuitions' have been based on some other principle or penal approach.").

${ }^{235}$ What, if anything, makes blackmail a crime is a matter of considerable debate. For a sampling of the various positions, see Symposium, Blackmail, $141 \mathrm{U} \mathrm{Pa}$ L Rev 1565 (1993).

${ }^{206}$ See Waldron, 34 Ariz L Rev at 44-45 (cited in note 202); id at 45 ("If the wrongness of [blackmail] has to do with its exploitation of the victim's vulnerability, again it is not hard to imagine possible modes of retribution.").

${ }^{27}$ See id at 46 ("LLex talionis] will recognize a distinction between intention and recklessness in regard to the causation of death and vary the punishment accordingly."). 
Obviously, these suggestions are deeply problematic and bring to mind all kinds of objections. Would we really want, for example, to deny a perjurer access to the courts for wrongs of all kinds? Would nothing about an offender's life be off limits? Should punishment itself, even for reckless or negligent conduct, purposefully be made subject to a role of the dice?

In fairness, Waldron offers these ideas only to suggest ways of thinking about lex talionis. They are not meant to be welldeveloped proposals for practical reform. In the end, it may not be appropriate to apply lex talionis in anything even remotely like the ways suggested. But that is no argument against applying it where it is appropriate, as it is with many of the offenses now subject to innovative sanctioning.

Moreover, although recasting lex talionis and linking it to the moral reform theory of punishment avoids many of the problems traditionally leveled against lex talionis, doing so creates other problems. For example, the moral reform theory works best when sentencing is individualized. It calls upon the creativity and imagination of the sentencing judge to figure out just what punishment would "fit" a particular offender and his particular offense, and to identify what kind of imposition would best serve the educative mission lex talionis sets for itself. Talionic punishments thus require considerable toleration of judicial discretion and diversity in punishment.

This toleration not only swims against the current trend toward uniformity and rule-based sentencing guidelines, it also invites the kinds of problems that produced this trend in the first place. Among other things, the more individualized sentencing becomes, i.e., the more room that exists for judges to take account of the particular facts and circumstances of an offender and an offense, the more room exists for the exercise of bias and prejudice. Moreover, individualized sentencing also makes it more difficult to determine whether similarly situated offenders have been treated similarly. That judgment will become even more difficult if the universe of possible sanctions is opened up to include talionic punishments, which would make that universe itself qualitatively more diverse as a result. ${ }^{238}$

${ }^{23}$ See von Hirsch, Censure at 76 (cited in note 64) (arguing that "making the punishment fit the crimen would lead to a proliferation of sentences and make severity comparisons harder). 


\section{EDUCATING THROUGH PUNISHMENT}

The shaming model explains many of the punishments that have recently received widespread attention. Examples include: Requiring a shoplifter to stand outside the store from which she stole wearing a sign, "I stole from this store. Don't be a thief. This could happen to you"; requiring drunk drivers to attach a "CONVICTED: DWI" bumper sticker to their cars; and displaying in the newspaper, or on local cable access TV, the names and faces of men caught soliciting prostitutes. ${ }^{239}$ All these sanctions may successfully condemn and shame. They may even be effective deterrents, but they do little to educate.

Other creative punishments are sometimes described as shaming penalties, ${ }^{240}$ but they don't actually fit the shaming model very well, largely because they don't require the offender to disclose his offense to an audience that would not normally already be aware of it. Many of these sanctions do, however, fit the educating model and are better seen as talionic. Rather than serve as mechanisms of shame, they are instead intended to set in motion the moral sequence of perception of wrongdoing, guilt, and repentance.

I break these sanctions down into two types: talionic punishments and talionic restitution. I also discuss how apology rituals, which are not talionic, fit within the educating model.

\section{A. Talionic Punishments}

Talionic punishments force an offender to somehow experience the harm he has caused. Although these sanctions appear to be relatively rare compared with shaming penalties like signs and bumper stickers, they do pop up from time to time.

For example, Judge Joe Brown of Memphis, Tennessee ordered a robber to allow his victim (accompanied by police officers) to enter the robber's home and take something of similar value to what the robber had taken from the victim. ${ }^{241}$ Similarly, a New York City slumlord was sentenced to house arrest in one of his own slums where his tenants greeted him with a sign, "Welcome Reptile! ${ }^{\$ 242}$ Such talionic sanctions, which hopefully carry an edu-

${ }^{239}$ See notes 9-10, 12 and accompanying text.

${ }^{210} \mathrm{See}$, for example, Kahan, $63 \mathrm{U}$ Chi L Rev at 631-34 (cited in note 31).

${ }^{21}$ See Brown, Instructional Penalties, NY Times at B16 (cited in note 16).

${ }^{212}$ See Instead of Jail, NY Times at A22 (cited in note 15). But compare Andrew von Hirsch, Punishment to Fit the Criminal, The Nation 901-02 (June 25, 1988) (noting that one "slumlord was able to thwart the intent of his punishment by bringing along his own repairmen and guards"). 
cative message, should be contrasted with the kinds of sanctions the shaming model would recommend under similar circumstances. For example, under the shaming model the thief might simply be forced to wear a sign publicizing his crime, while the landlord might be forced to post a sign on his property proclaiming it a slum.

Finding ways to punish men guilty of soliciting prostitutes also brings out the contrast between shaming and educating. The shaming model recommends simply publicizing the names of these men in the local newspaper or on local cable TV. The educating model, in contrast, endorses a different strategy, which can be seen at work in San Francisco's "School for Johns." ${ }^{243}$ Firsttime offenders arrested in San Francisco for soliciting prostitutes don't have charges filed against them. Instead, they are required to pay $\$ 500$ and attend an all-day seminar, officially called the "First Offender Prostitution Program," but commonly known as the "School for Johns." After an assistant district attorney tells them what they can expect by way of jail time if they get caught again, the "students" receive lectures from former prostitutes who describe tragic and horrible stories of life on the street, detailing the social consequences of prostitution as well as the medical risks. ${ }^{244}$ The men thus learn about the harms to which their conduct contributes, whether or not they take the lesson to heart.

Or consider the following example of talionic punishment from Gastonia, North Carolina, where a man rammed his car into an auto being driven by an interracial couple. ${ }^{245}$ Maybe the only harm the offender caused was the damage done to the couple's vehicle, in which case it might have been fitting for the offender to have been forced to repair the car, or to have been denied access to his own car for some period of time. The judge, however, thought the damage to the car was not what really made the offender's act wrong. What made it wrong was the racist message it conveyed. Consequently, the judge ordered the man to watch "Mississippi Burning," a movie recounting the struggle for civil rights in Mississippi. ${ }^{246}$ The hope was that the man might learn a lesson in toleration.

${ }^{2 \times 3}$ See Deutschman, Playboy at 46 (cited in note 13 ).

${ }^{2 \mu}$ See id. See also Cemetery Vandals Told to Attend Funeral, UPI (Jan 22, 1988) (A judge ordered cemetery vandals to attend funeral in order to teach them "how the dead are venerated in our culture' and why the community was outraged."); Making the Punishment Fit the Crime, Chi Trib 24 (May 28, 1992) (editorial) (Drunk drivers forced to attend similar confrontation sessions.).

${ }^{245}$ See Mississippi Burning, UPI (cited in note 19).

${ }^{216} \mathrm{Id}$. 
A similar approach to crimes of intolerance has been used in Los Angeles where, as part of a negotiated plea, fourteen members of the Fourth Reich Skinheads were forced to participate in a program designed to "enlighten and frighten." tion Grow Hair," the skinhead members met with U.S. District Judge Terry Hatter, who is African-American; saw "Schindler's List"; toured the Simon Wiesenthal Center; listened to the stories of two Holocaust survivors; and met with a prominent preacher who some of the skinheads had plotted to kill. ${ }^{248}$ Again, the punishment was geared to teach, regardless of whether or not the lesson ultimately took hold.

The talionic element of these punishments is admittedly attenuated. Indeed, to describe it as "talionic" may be more misleading than it is illuminating. Nonetheless, insofar as they try to impress upon the offender in as concrete and vivid a way as possible the nature of the harm he has caused, I submit that they can still be looked upon as "talionic," even if they don't require the offender to experience those harms more directly.

In any event, notice again that none of these sanctions are strictly speaking shaming penalties (though they might qualify as "guilting" penalties), because none require an offender to publicize his wrongdoing. Of course, because they are so out of the ordinary, punishments of this sort naturally tend to attract a good deal of media publicity, and so awareness of the offender's wrongdoing usually reaches a wider audience than it otherwise would. But the publicity is not part of the sanction. It is the sanction's novelty that produces the publicity, not the sanction itself.

While these talionic punishments do, under the right circumstances, seem at least capable of hitting their educative mark, others seem more likely to miss it. Talionic punishments misfire for a variety of reasons. Sometimes they misfire because they accentuate an aspect of the offender's wrongdoing that is morally irrelevant. For example, Judge Ted Poe of Houston, Texas, known as the "King of Shame," two girls to whom he had given piano lessons to "donate" his piano to a children's home and prohibited him from playing the pi-

${ }^{217}$ Jim Newton, Skinheads Get Crash Course in Tolerance, Star-Trib 5A (Jan 1, 1994). See also Judge Orders Victim of Theft to Steal from Thief, St. Petersburg Times 7A (Oct 3, 1991) (describing judge who orders defendants to watch "Boyz $\mathrm{N}$ the Hood" apparently in an effort to scare them straight); Michener Offers To Teach Vandals About Holocaust, Chi Trib C24 (June 7, 1990) (Youths convicted of anti-Semitic vandalism required to read chapter about the Holocaust from John Michener's book Poland.).

${ }^{248}$ Newton, Skinheads, Star-Trib at 5A.

${ }^{21}$ Kelly McMurry, For Shame: Paying For Crime Without Serving Time, But With A Dose of Humility, Trial 12 (May 1, 1997). 
ano for ten years. ${ }^{250} \mathrm{~A}$ sanction like this may qualify as talionic in some weak sense, but it conveys no real lesson. It pays too much attention to the poetic justice of talionic punishments and too little attention to their educative function. ${ }^{251}$

At other times, it is harder to separate out the relevant from the irrelevant. For example, a judge in Tampa, Florida, sentenced a man whose reckless driving had resulted in the death of a teenager to two years house arrest and three years probation. The accident had occurred on Thanksgiving day. Consequently, during the five year span of his sentence, the man was required to spend Thanksgiving and Christmas in the local jail. ${ }^{252}$ Generally the date on which a crime occurs is morally irrelevant; however, here the timing of the teenager's death does appear relevant to the harm the offender caused, because the happiness typically associated with those holidays will for the victim's family now be associated with sadness. The offender will be denied the warmth of family and friends during the holidays, just as his actions denied that warmth to his victim's family.

Other talionic punishments don't just misfire; they backfire. They treat the offender as less than a person, and in so doing teach the wrong lesson. For example, an Ohio judge is reported to have required an offender convicted of spousal abuse to stand still while his wife spat in his face. ${ }^{253}$ Although a part of the husband's abuse consisted of him spitting in her face, allowing her to spit in his goes too far in the direction of literal lex talionis. Even if we have under the circumstances little concern for the husband's dignity and moral status, we should still be concerned about the corrupting effects that such treatment may have on the character of his spouse, as well as on that of the rest of us. ${ }^{254}$

${ }^{250}$ See Gary Taylor, Texas Defendants Receive Additional Poe-etic Justice, Natl L J A23 (July 18, 1994).

${ }^{21}$ Likewise, forcing offenders who are doctors to provide health care, or dentists to provide dental care, has a poetic quality to it, but it typically lacks any educational value. See, for example, Creative Difficulties, Natl L J 51 (Feb 7, 1994) (describing Judge Poe's practice of sentencing probationers to community service reflecting their occupation). See also Rock Manager Convicted on Drug Charges to Use Music to Fight Drugs, UPI (Apr 26, 1988) (Manager of Bon Jovi and Motley Crue required to use industry connections to make an antidrug documentary and stage an antidrug rock concert.).

${ }^{252}$ See Sue Carlton, Hell Spend Holidays in Jail for Fatal Wreck, St. Petersburg Times $1 \mathrm{~A}$ (Oct 20,1995). See also Ron Schara, Hunter Will Be Cooling Heels in Jail for Deer Season, Star Trib 19C (Oct 20, 1991) (A hunter convicted of illegal killing of black bear required to spend deer season in jail.).

${ }^{253}$ See Greenhut, Milwaukee J Sent at A11 (cited in note 28). I realize that reasonable people will react differently to the examples I discuss in the text. For example, although I found the spitting example troubling, I discovered colleagues who liked it.

${ }^{244}$ See Waldron, 34 Ariz L Rev at 38 (cited in note 202) (noting tendency of literal lex talionis to "encourage... nasty sadism"). 
An even clearer case of going too far comes once again from the courtroom of Judge Joe Brown. Recall that one of Judge Brown's creative, and appropriately talionic, punishments is to allow victims of robbery to enter the home of the offender and remove something of comparable value. In one case, however, the thief had nothing of monetary value for the victim to take. Instead, the victim took a picture of the thief's deceased girlfriend and burned it in front of him. ${ }^{255}$ Such an exercise teaches no one any lesson worth learning. On the contrary, it conveys a lesson in callousness.

\section{B. Talionic Restitution}

Unlike talionic punishments, talionic restitution does not require the offender to more or less directly experience the harm he has caused. Instead, it tries to impress upon him the harm he has done and hopefully teach the requisite lesson by forcing him to repair it.

Talionic restitution differs from simple restitution. Simple restitution focuses on compensating the victim much as tort law does. ${ }^{256}$ As such, simple restitution merely requires the offender to pay for the material harm he has caused. Money changes hands, but not much else. Simple restitution is therefore nontalionic.

However, restitution can take on a talionic cast. Indeed, one of the earliest proponents of restitution in the criminal law, Albert Eglash, argued long ago that the "restitutional act has a poetic justice about it." ${ }^{257}$ As an example of what he had in mind, he mentioned the auto thief who "can offer to wash the victim's car each Saturday for a month, or to Simonize it, or repair some mechanical difficulty. ${ }^{3258}$ A more contemporary example might be requiring graffiti "artists" to clean up their handiwork. ${ }^{259}$ Such an

\footnotetext{
${ }^{255}$ See Humiliation, Salt Lake Trib at A1 (cited in note 16) (reporting that the thief cried as the picture was being burned).

${ }^{256}$ See Randy Barnett, Restitution: A New Paradigm of Criminal Justice, 87 Ethics 279,289 (1977) (describing "pure" restitutional system as one in which the "point" is not the offender's suffering, but the offended party's compensation). Talionic restitution is also different from community service, because talionic restitution, unlike community service, requires the offender to repair the particular kind of harm he has caused, not simply to provide some general service to the community.

${ }^{25 z}$ Albert Eglash, Creative Restitution, A Broader Meaning for an Old Term, $48 \mathrm{~J}$ Crim L, Criminol \& Pol Sci 619, 620 (1958).

${ }^{2 x 8} \mathrm{Id}$.

${ }^{259}$ See, for example, George Frank, Graffiti Cleanup Is Possible Punishment, LA Times B3 (Apr 12, 1990). See also "T've Never Had Anybody Run Over a House Before", UPI (May 14, 1982) (A college student convicted of DWI who crashed his car into a house was given the option to paint the house after it had been repaired in order to reduce his jail sen-
} 
approach, if it succeeds, is doubly virtuous. Not only does the offender repair the material damage he has caused, but with luck, he comes in the course of his efforts to better understand the impact of the harm he has caused. Moreover, and with more luck, the offender also learns that making amends-repairing the damage-is the proper moral response to wrongdoing.

Many creative punishments are examples of talionic restitution. Judge Larry Schack, for example, ordered an eighteen-yearold offender who had stolen $\$ 468.42$ worth of food from a local Winn-Dixie to work at the store. The judge's aim was educative. As he said to the eighteen-year-old: "I want you to get to know the people who manage the store. ... I want you to know the people you tried to steal from. ${ }^{.260}$ Perhaps the offender might be required to work until he paid off the $\$ 468.42$, with the idea that he might learn the value of that sum to his victims. An educative sanction of this kind stands in marked contrast to the shaming model's way of dealing with shoplifters, which is simply to require them to stand in front of the store wearing a sign announcing their offense.

Judge Walter Williams of Chattanooga, Tennessee, is especially good at the art of talionic restitution. He has, for example, required a man convicted of breaking into a church to shine the pews and an offender guilty of setting off fire alarms to polish the city's fire trucks. ${ }^{261}$ While these restitutionary acts may not force the offenders to repair the specific harm they caused, they do bring them into contact with members of the church and the city's fire department, respectively, and in so doing may work to educate the offenders. In the case of the church, the offender may come to learn how sacred the church property is to its members, and in the case of the firemen, how dangerous and wasteful it is for firemen to be forced to respond to false alarms. And these do, after all, seem to be the kinds of lessons the offenders need to learn.

If talionic punishments sometimes misfire when they become "too talionic," talionic restitution can misfire when it becomes "too restitutionary," placing emphasis more on compensating than on educating. In both cases the educational thrust of the sanction is

tence.).

${ }^{200}$ Monica Davey, Judge Imposes Shame with His Sentences, St. Petersburg Times Al (Feb 16, 1997).

${ }^{201}$ See The Give Em Hell Judge: Justice with an Iron Fist, Newsweek 22 (Feb 6, 1995). See also Charlotte Libov, Creative Sentences for Youths, NY Times 11CN (July 14, 1985) (Two Connecticut youths arrested for setting fire to pile of leaves required to "wash[] down the fire truck at the local firehouse."). 
lost. For example, a Connecticut defendant convicted of a hit-andrun that resulted in serious injury to the victim was sentenced to a term of incarceration, part of which was suspended, and five years probation. ${ }^{262}$ As a condition of probation, he was required to make a charitable "donation" of $\$ 2,500$ to the New Britain Hospital where the victim of the hit-and-run had been treated. ${ }^{263}$ While such a condition may look talionic insofar as it links the required "charitable" act to the hospital that treated the victim, ${ }^{264}$ it does little to impress upon the offender the nature of his wrongdoing. ${ }^{265} \mathrm{He}$ simply sends in his check without really repairing the harm he has caused. Requiring the offender to work in the hospital's trauma ward, where he could witness firsthand the human consequences of hit-and-runs, would have been a better approach. ${ }^{266}$ Talionic restitution is also different from community

${ }^{202}$ State v Pieger, 42 Conn App 460, 680 A2d 1001, 1005 (1996), affd, 240 Conn 639, 692 A2d 1273 (1997).

Id at 1005-06. For other examples of offenders who have been forced to join or donate money to an organization or institution, see Edmond's Money Sought for Babies, Wash Post D5 (Feb 8, 1990) (nonprofit public interest law group urging drug dealer be forced to pay \$3.96 million to D.C. General Hospital to help care for "crack babies"); Judy Farah, Rule of Law: Crime and Creative Punishment, Wall St J A15 (Mar 15, 1995) (reporting that a man convicted of hitting a woman was forced to donate car to local battered women's shelter); Judge Gives Gun Violators Unusual Sentence, UPI (Oct 10, 1982) (reporting that gun law violators were allowed to join gun control organizations in lieu of imprisonment). See also He Finds a Way to Be Heard, Natl L J A23 (July 28, 1997) (reporting that singer Barry Manilow agreed to donate $\$ 5,000$ to the American Tinnitus Association in order to settle civil suit brought by judge who claimed his hearing was damaged at a 1993 Manilow concert). See generally Jaimy M. Levine, Comment, "Join the Sierra Club!": Imposition of Ideology as a Condition of Probation, $142 \mathrm{U} \mathrm{Pa} L \mathrm{Rev} 1841,1874-77$ (1994) (collecting examples of "ideology-related" probation conditions).

${ }^{25}$ According to the court, however, the "donation [was] a realistic method of making the defendant aware of the damage he has wrought as a result of his offense." Pieger, 680 A2d at 1005-06.

${ }^{258}$ This, of course, is less true when the offender is actually required to work for the charity, in which case he may learn the value of the goal to which it is dedicated. See, for example, Ronald Sullivan, Beer-Flinger Sent to a Fitting Cooler: Gay-Rights Office, NY Times B1 (May 22, 1991) (A man convicted of throwing beer can at Mayor Dinkins "as he marched with a contingent of gay Irish in St. Patrick's Parade . . . [was] sentenced to a week of duty in the Mayor's Office for the Lesbian and Gay Community.").

${ }^{258}$ Similarly, Cook County Judge Marcia Orr required a man who injured a friend with a baseball bat to spend four weekends in the county morgue and to work five hundred hours at the Rehabilitation Institute of Chicago. See John Lucadamo, Evanston Beating Nets Probation: Assailant Must Spend Time in Morgue, Chi Trib C3 (Apr 7, 1992). See also Charles Fishman, Autopsy Sentence Altered to Rescue-Squad Ride, Wash Post B3 (Mar 27, 1984) (A reckless driver, originally required to view autopsy, ordered instead to ride for two nights with a rescue squad.); Lanie Jones, "Shock Treatment" for Drunk Drivers: Visiting a Morgue, LA Times 1 (Aug 21, 1987) (reporting convicted drunk drivers ordered to spend two hours at the county morgue and ten hours at a hospital trauma center); Two Football Players Sentenced for Arson, UPI (Apr 19, 1985) (Two football players guilty of arson ordered to "respond[ ] to the scenes of fires where a victim has died and then writ[e] an essay about the experience."). 
service, because talionic restitution, unlike community service, requires the offender to repair the particular kind of harm he has caused, not simply to provide some general service to the community. ${ }^{267}$

Talionic restitution can misfire even worse if the restitution bears no relationship whatsoever to the offense. For example, Houston's Judge Poe ordered a man convicted of child abduction to clean the stables of the Houston mounted police. ${ }^{268}$ While the work may have been unpleasant, and even shameful, it was hardly educative. A closer case comes from Baltimore, Maryland, where Judge Edward Angeletti ordered a man convicted of selling fake insurance policies to Maryland horse trainers to clean out the stalls of the city's mounted police unit. ${ }^{269}$ The fit between the crime and the punishment looks tighter, but it still seems more poetic than educative. The same goes for the sanction imposed on a man convicted of plucking feathers from two golden eagles, a federal offense. He was required to work in a chicken processing plant. ${ }^{270}$ Again, the punishment may have been talionic, but its educational potential was dubious.

\section{Apology Rituals}

One popular form of creative punishment is the apology ritual. ${ }^{271}$ Usually the offender is forced to make a public apology, in which case the ritual is best seen as a shaming penalty, since the

${ }^{207}$ See Barnett, 87 Ethics at 288-91 (cited in note 256).

See Elizabeth Levitan Spaid, Humiliation Comes Back As Criminal Justice Tool, Christian Sci Mon 1 (Dec 17, 1996). See also Gary Taylor, Batman Comics Thieves Get Creative Punishment, Natl L J 43 (May 13, 1991) (One youth convicted of stealing comic books required to do odd jobs in public library, and two others required to read books to children at county hospital.); Judge's Penalties Offer Food For Thought and For the Poor, Natl L J A24 (Oct 27, 1997) ("[N]onviolent, petty offenders" convicted of offenses such as speeding and bad check writing required to pay fines in food that is distributed to the poor.).

${ }^{200}$ See Maryland Stable Duty, Wash Post at D5 (cited in note 20).

${ }^{270}$ See Around the Nation: Addenda, Wash Post A20 (Feb 2, 1996).

${ }^{2 n}$ See, for example, Jay Mathews, Freedom Means Having to Say You're Sorry; Criminal Justice System Tries an 'Apology Ad' Program as an Alternative to Prison, Wash Post A3 (Nov 9, 1986) (describing "apology ad" program in Newport, Oregon); Jim Runnels, Public Apology is Man's Sentence for Assaulting Police Officers, Orlando Sent 1 (June 7, 1990) (A man accused of assaulting police required to place an ad in the local paper apologizing for his behavior.); Russell, Good Housekeeping at 201 (cited in note 9) (A man convicted of spousal abuse required to "publicly apologize to [his wife] on the steps of city hall at noon."). See also United States $v$ Clark, 918 F2d 843, 848 (9th Cir 1990), overruled on other grounds in United States $v$ Kays, 95 F3d 874 (9th Cir 1996) (upholding published public apology as a condition of probation and noting that "a public apology may serve a rehabilitative purpose"). 
emphasis is more on the shame of a public confession and less on the meaning of the apology itself.

However, apology rituals can also play a role in the educating model. From this perspective, the emphasis is on the apology and not on the shame that might accompany giving it in public. In fact, insofar as the shame of a public apology drowns out the meaning and significance of the apology itself, the educating model would urge the apology to be made in private, away from public view. What lesson, though, do apology rituals teach? And how do they fit within the educating model?

Apology rituals bear a noticeably different relationship to the educating model than do talionic punishments. Under the moral education theory, an apology and the desire to make amends should be the result of punishment, at least when the punishment "works," and not the punishment itself. Ideally, that is, the offender learns through his punishment the wrongfulness of what he has done and having realized its wrongfulness, voluntarily repents. The upshot of this process may be an apology. Genuine apologies produced in this fashion can have an almost magical character. Apologies "constitute-in their most responsible, authentic, and, hence, vulnerable expression-a form of selfpunishment that cuts deeply because we are obliged to retell, relive, and seek forgiveness for sorrowful events that have rendered our claims to membership in a moral community suspect or defeasible. ${ }^{\text {2272 }}$

On this view, therefore, the coerced apologies at the center of apology rituals are simply outside the ambit of the moral reform theory. An apology must be the consequence of punishment and the only good apology is a sincere apology.

But this way of looking at the value of an apology and the scope of the moral reform theory is too narrow. While a sincere apology is the ideal, we shouldn't underestimate the educational value of a formal apology, whether or not we believe it to be sincere. Parents routinely tell their misbehaving children to "say you're sorry," without any real hope of sincerity. Why? Because the exercise itself teaches a valuable lesson. The emphasis in apology rituals can be as much on the ritual as on the apology. ${ }^{273}$

${ }^{222}$ Nicholas Tavuchis, Mea Culpa: A Sociology of Apology and Reconciliation 8 (Stanford 1991). See also Erving Goffman, Relations in Public: Microstudies of the Public Order 113-14 (Basic Books 1971) (discussing apologies).

${ }^{273}$ See Jeffrie G. Murphy, Forgiveness and Resentment, in Jeffrie G. Murphy and Jean Hampton, Forgiveness and Mercy 14, 28 (Cambridge 1988) ("Sometimes ... [an] apology is more than mere ritual. ... At other times we will settle simply for the ritual-so long as it is not transparently insincere."). 
When we violate a rule of social intercourse and have no excuse or justification for our conduct, the proper response is to accept responsibility for our actions and to try to make amends, if only by making a simple apology. ${ }^{274}$ Thus, if talionic punishments try to teach the offender why his action was wrong in the hope that he will voluntarily respond with an apology, apology rituals try to teach him in a more direct fashion what the proper moral response to wrongdoing is by forcing him to apologize.

Moreover, this approach to apology rituals suggests that existing rituals, which only require an apology from the offender, are incomplete. Ideally, apologies are not one-sided affairs. On the contrary, a "proper and successful apology is the middle term in a moral syllogism that commences with a call [for apology] and ends with forgiveness. ${ }^{2275}$ Some crimes may be unforgivable, and forgiving too readily may be more vice than virtue. ${ }^{276}$ Under the right circumstances, however, the proper response to a sincere apology is to accept it, and going one step further, to forgive. So if we are more concerned with the educative function of "going through the motions" than with sincerity, then perhaps offenders should not be forced to issue an apology unless the victim is prepared, however insincerely, to "accept" it.

In the moral economy of apology, the state acts as a teacher both for offenders and victims. Apologizing and forgiving, like any form of social and moral tuition, must be taught and learned. ${ }^{277}$

${ }^{274}$ See Tavuchis, Mea Culpa at 13 (cited in note 272).

${ }^{275}$ Id at 20.

${ }^{278}$ See Murphy, Forgiveness and Resentment at 17 (" $[\mathrm{A}]$ too ready tendency to forgive may properly be regarded as a vice because it may be a sign that one lacks respect for oneself."). See also Sharon Lamb, The Trouble With Blame: Victims, Perpetrators, and Responsibility 163-66 (Harvard 1996) (describing circumstances under which forgiveness can be part of the "abusive cycle" endured by battered women).

${ }^{27}$ See Tavuchis, Mea Culpa at 65 (cited in note 272). Apologies play a much larger role in the Japanese criminal justice system than in the United States. See John O. Haley, Sheathing the Sword of Justice in Japan: An Essay on Law Without Sanctions, 8 J Japanese Stud 265, 269 (1982) ("Confession, repentance, and absolution provide the underlying theme of the Japanese criminal process."). See also V. Lee Hamilton and Joseph Sanders, Punishment and the Individual in the United States and Japan, 22 L \& Society Rev 301, 324 (1988) (presenting survey data indicating that "American respondents . . . favor retributive reasons for punishing and Japanese ... more reintegrative reasons. ${ }^{\text {"); }}$;iroshi Wagatsuma and Arthur Rosett, The Implications of Apology: Law and Culture in Japan and the United States, 20 L \& Society Rev 461, 464 (1986) (noting that the "availability of social restorative mechanisms like apology [in Japan] obviates formal legal sanctions in many cases").

Moreover, in Japan the sincerity of an apology is less a matter of the offender's internal state of mind, as it is in the United States, and "more a matter of performing the correct external acts" that "reaffirm submission" to an accepted order. See Wagatsuma and Rosett, $20 \mathrm{~L}$ \& Society Rev at 492. Compare John O. Haley, Comment: The Implications of Apology, 20 L \& Society Rev 499, 504 (1986) (cautioning against using these differences to 
Coerced apologies, together with coerced forgiveness, should be looked upon as efforts to instruct, not so much about the wrongness of the offense, but about the virtues of remorse, forgiveness, and reconciliation. The offender is taught how he should respond to his wrongdoing, while the victim is taught "how to be angry in the service of forgiveness rather than vindictiveness. ${ }^{278}$

Like talionic punishments, apology rituals can, of course, misfire. Beyond the acceptable risk that an apology will simply be insincere is the unacceptable risk that an apology will take a pathological form. An apology may, for example, degenerate into "exhibitionism, self-pity, or . . . egocentric indulgence." ${ }^{279}$ In this case the apology, far from being an occasion for healing, becomes an opportunity for the offender to inflict additional harm. It may be for this reason that some courts order apologies to be made in writing, rather than in person. Not only can written apologies be approved by the court in advance, they also eliminate any risk that the delivery and performance of the apology will serve as an opportunity for yet more torment. On the downside, written apologies also eliminate the kind of reconciliation that can only come with a face-to-face encounter.

\section{CONCLUSION}

Creative punishments may not amount to anything more than relatively rare objects of curiosity. To the extent they become more than that, judges should realize that they come in two very different forms-shaming and educating. Many, though not all, of the creative punishments we see today fit the shaming model better than they do the educating model, but the appeal of shame is decidedly mixed. Judges looking for alternatives to incarceration and probation should therefore take a closer look at the didactic alternative to shame.

suggest we have nothing to learn from the Japanese experience).

${ }^{278}$ Tavuchis, Mea Culpa at 65 (cited in note 272).

${ }^{279}$ Id at 34. 